\title{
Review \\ Neuropsychiatric Disorders Due to Limbic Encephalitis: Immunologic Aspect
}

\author{
Yu-Chia Kao ${ }^{1}\left(\mathbb{D}\right.$, Ming-I Lin ${ }^{2}\left(\mathbb{D}\right.$, , Wen-Chin Weng ${ }^{3,4}\left(\mathbb{D}\right.$ and Wang-Tso Lee ${ }^{3,4,5, *}$ \\ 1 Department of Pediatrics, E-Da Hospital, Kaohsiung 82445, Taiwan; yukanomail2006@yahoo.com.tw \\ 2 Department of Pediatrics, Shin Kong Wu Ho-Su Memorial Hospital, Taipei 11101, Taiwan; \\ m000743@ms.skh.org.tw \\ 3 Department of Pediatrics, National Taiwan University Hospital, Taipei 100226, Taiwan; wcweng@ntu.edu.tw \\ 4 Department of Pediatrics, National Taiwan University College of Medicine, Taipei 100233, Taiwan \\ 5 Graduate Institute of Brain and Mind Sciences, National Taiwan University College of Medicine, \\ Taipei 100233, Taiwan \\ * Correspondence: leeped@hotmail.com; Tel.: +886-2-23123456 (ext. 71545); Fax: +886-2-23147450
}

check for updates

Citation: Kao, Y.-C.; Lin, M.-I; Weng, W.-C.; Lee, W.-T. Neuropsychiatric Disorders Due to Limbic Encephalitis: Immunologic Aspect. Int. J. Mol. Sci. 2021, 22, 389. https://doi.org/ 10.3390/ijms22010389

Received: 10 December 2020 Accepted: 28 December 2020 Published: 31 December 2020

Publisher's Note: MDPI stays neutral with regard to jurisdictional clai$\mathrm{ms}$ in published maps and institutional affiliations.

Copyright: () 2020 by the authors. Licensee MDPI, Basel, Switzerland. This article is an open access article distributed under the terms and conditions of the Creative Commons Attribution (CC BY) license (https:// creativecommons.org/licenses/by/ $4.0 /)$.

\begin{abstract}
Limbic encephalitis (LE) is a rare cause of encephalitis presenting as an acute and subacute onset of neuropsychiatric manifestations, particularly with memory deficits and confusion as core features, along with seizure occurrence, movement disorders, or autonomic dysfunctions. LE is caused by neuronal antibodies targeting the cellular surface, synaptic, and intracellular antigens, which alter the synaptic transmission, especially in the limbic area. Immunologic mechanisms involve antibodies, complements, or T-cell-mediated immune responses in different degree according to different autoantibodies. Sensitive cerebrospinal fluid markers of LE are unavailable, and radiographic findings may not reveal a typical mesiotemporal involvement at neurologic presentations; therefore, a high clinical index of suspicions is pivotal, and a neuronal antibody testing is necessary to make early diagnosis. Some patients have concomitant tumors, causing paraneoplastic LE; therefore, tumor survey and treatment are required in addition to immunotherapy. In this study, a review on the molecular and immunologic aspects of LE was conducted to gain awareness of its peculiarity, which we found quite different from our knowledge on traditional psychiatric illness.
\end{abstract}

Keywords: limbic encephalitis; neuropsychiatric; neuronal cell-surface antibody; onconeural antibody; paraneoplastic neurologic syndrome

\section{Introduction}

Limbic encephalitis (LE) is an inflammatory encephalitis involving the limbic system, which encompasses the medial temporal lobe, hippocampus, and frontobasal and cingulate cortex [1]. LE is frequently associated with antibodies against the neuronal cell surface, synaptic vesicles, and intracellular proteins; therefore, it belongs to the autoimmune encephalitis (AE) category. Triggering factors include tumors, viral infections, or immune check point inhibitors (ICI's) [2,3]. LE most often occurs in adults older than 45 years but can affect people of all ages. In addition, gender predominance varies with the type of antibody.

The clinical hallmark of LE includes acute and subacute onset of memory and cognitive deficits. Other symptoms include confusion, psychiatric symptoms (such as anxiety, depression, or psychosis), behavioral changes, seizures, movement disorders (such as ataxia, dystonia, or myoclonus), autonomic disturbances, and sleep disturbances [1,4]. The amygdala is a core region of the limbic system involved in the control of positive and negative affect, modulation of memory, and social and cognitive functions as well as behavioral adaptation to stress [5], which explains the core neuropsychiatric manifestations of LE. The basolateral complex of the amygdala is the main input site for sensory information from the thalamus and cortical regions, which plays a central role in seizure generation, particularly in the temporal lobe epilepsy [6]. 
According to Graus et al., the diagnosis of LE requires four criteria: (1) subacute onset (<3 months) of cognitive deficits, seizures, or psychiatric symptoms; (2) brain abnormalities in the medial temporal lobes on T2-weighted and fluid-attenuated inversion recovery magnetic resonance imaging (FLAIR MRI) images; (3) cerebrospinal fluid (CSF) pleocytosis $\left(>5\right.$ cells per $\mathrm{mm}^{3}$ ) or an electroencephalography (EEG) showing epileptic discharges or slow-wave activity involving the temporal lobes; and (4) exclusion of alternative causes [1] With time, the radiographic features of swelling and hyperintensity in the limbic structures may progress to mesiotemporal atrophy [7]. Some cases showed abnormalities in the basal ganglia, particularly those with leucine-rich glioma inactivated 1 (LGI1) antibody presenting with faciobrachial dystonic seizures [8,9]. In some cases, MRI may show only unilateral limbic or extralimbic involvement, and even normal finding, making the diagnosis a challenge. Fluorodeoxyglucose (FDG)-positron emission tomography (PET) is more sensitive than EEG and MRI in detecting abnormalities in LE, particularly in LGI1 and contactin-associated protein-like 2 (CASPR2) encephalitis $[9,10]$. A positive neuronal antibody is frequent but not mandatory for diagnosis as around $7-26 \%$ of LE cases had no detectable antibodies and are referred to as seronegative [11]. Positive antibody results are useful in diagnosing patients with atypical features or those who do not fulfill the Graus's criteria [1].

\section{Antibodies}

Antibodies associated with LE are thought to be of peripheral origin that penetrates a leaky blood-brain barrier (BBB) or to be synthesized intrathecally. Most AE has higher serum than CSF antibody levels, implicating that antibodies are likely to be initiated by a peripheral immune response [12]. The autoantibodies are predominantly of IgG1 subclass. However, LGI1 and CASPR2 antibodies are mainly IgG4 subclass [13,14]. IgG4 antibody is hetero-bispecific (continuously undergoing half antibody exchange), hence less effective than IgG1 in crosslinking and internalizing the target antigen and does not fix complement [15]. In general, IgG1-associated AE (e.g., N-methyl-D-asparate receptor [NMDAR], $\gamma$-aminobutyric acid-B receptor [GABA-BR], and $\alpha$-amino-3-hydroxy-5-methyl4-isoxazolepropionate receptor [AMPAR]) have more inflammatory signs than IgG4associated AE (e.g., LGI1 and CASPR2) [16]. Nevertheless, complement-mediated neuronal loss was still observed in LGI1 and CASPR2-associated neurologic syndromes [17,18]. These patients had higher complement-fixing IgG1 subclass with more prolonged clinical course, more severe cognitive impairment, and frequent hippocampal atrophy in advanced stages of the disease $[13,19]$.

Antibodies associated with LE target: (1) cell-surface receptors (GABA, AMPA, and glycine receptors); (2) ion channels (voltage-gated potassium channels [VGKC]); (3) neighboring proteins that stabilize channel complex into the membrane (LGI1 and CASPR2); (4) enzymes that catalyze the formation of neurotransmitters glutamic acid decarboxylase (GAD); and (5) intracellular proteins ( $\mathrm{Hu}, \mathrm{Ma} 2$, collapsin response-mediator protein-5 [CRMP5], and amphiphysin) [20]. These antibodies are classified as neuronal cell surface, synaptic vesicle, and intracellular antibodies according to the location of their targeting antigens (Table 1). Antibodies against intracellular antigens are also known as onconeural antibodies because of their large association with tumors, and cause paraneoplastic syndromes (PNS) [21]. Pathologic effects include direct blockage of receptors and ion channels, indirect disruption with neighboring molecules interaction, and crosslinking and internalization of receptors to deplete them from the cell surface (Figure 1). 
Table 1. Autoantibodies associated with limbic encephalitis.

\begin{tabular}{|c|c|c|c|c|}
\hline & Symptoms & Tumor Association & Image & Prognosis \\
\hline \multicolumn{5}{|c|}{ Cell-surface } \\
\hline LGI1 & $\begin{array}{l}\text { LE, seizure including FBDS, } \\
\text { hyponatremia, paroxysmal } \\
\text { dizziness spells, pain, } \\
\text { dysautonomia }\end{array}$ & $\begin{array}{c}<10 \% \\
\text { SCLC, thymoma }\end{array}$ & $\begin{array}{c}\text { Normal or nonspecific } \\
\text { changes; T2-mesiotemporal } \\
\text { hyperintensity; T1-bright basal } \\
\text { ganglia in FBDS }\end{array}$ & $\begin{array}{l}\text { Almost fair response to } \\
\text { immunotherapy but high } \\
\text { relapse rate }(15-35 \%)\end{array}$ \\
\hline CASPR2 & $\begin{array}{l}\text { LE, Morvan syndrome, } \\
\text { neuromyotonia, seizure, } \\
\text { neuropathic pain, } \\
\text { dysautonomia }\end{array}$ & $\begin{array}{l}\text { 10-40\% (44\% for LGI1 and } \\
\text { CASPR2 dual seropositivity) } \\
\text { thymoma }\end{array}$ & $\begin{array}{c}\text { Normal or nonspecific } \\
\text { changes; T2 mesiotemporal } \\
\text { hyperintensity }\end{array}$ & $\begin{array}{l}\text { Favorable response to } \\
\text { immunotherapy but high } \\
\text { relapse rate }(35 \%)\end{array}$ \\
\hline AMPAR & $\begin{array}{l}\text { LE, confusion, psychiatric } \\
\text { symptoms, seizure }\end{array}$ & $\begin{array}{c}50-70 \% \\
\text { lung, breast, thymoma }\end{array}$ & $\begin{array}{l}\mathrm{T} 2 \text { mesiotemporal } \\
\text { hyperintensity }\end{array}$ & $\begin{array}{l}\text { Favorable response to } \\
\text { immunotherapy but } \\
\text { common relapse }\end{array}$ \\
\hline GABA-BR & $\begin{array}{l}\text { LE, seizure, dysautonomia, } \\
\text { movement disorder, rapidly } \\
\text { progressive dementia }\end{array}$ & $\begin{array}{l}50-60 \% \\
\text { SCLC }\end{array}$ & $\begin{array}{l}\mathrm{T} 2 \text { mesiotemporal } \\
\text { hyperintensity }\end{array}$ & $\begin{array}{c}\text { Frequent co-expression with } \\
\text { other Abs; poor prognosis } \\
\text { with concurrent tumor or } \\
\text { convulsive SE; relapse rate } \\
(20 \%)\end{array}$ \\
\hline mGluR5 & $\begin{array}{l}\text { LE, Ophelia syndrome } \\
\text { seizures, movement disorders }\end{array}$ & $\begin{array}{c}50 \% \\
\text { Hodgkin lymphoma }\end{array}$ & $\begin{array}{l}\text { Limbic and extra-limbic } \\
\text { (thalamus, pons, frontal or } \\
\text { parieto-occipital cortex, } \\
\text { cerebellum) }\end{array}$ & $\begin{array}{c}\text { Complete or partial recovery } \\
\text { to immunotherapy }\end{array}$ \\
\hline DPPX & $\begin{array}{c}\text { LE, BE, diarrhea, CNS } \\
\text { hyperexcitability, PERM, } \\
\text { dysautonomia }\end{array}$ & $\begin{array}{l}<10-30 \% \\
\text { B cell tumor }\end{array}$ & $\begin{array}{c}\text { Normal or nonspecific } \\
\text { T2/FLAIR white matter } \\
\text { abnormalities }\end{array}$ & $\begin{array}{l}\text { Chronic and second-line } \\
\text { immunotherapy frequently } \\
\text { required, relapse rate }(23 \%)\end{array}$ \\
\hline \multicolumn{5}{|c|}{ Synaptic } \\
\hline GAD & $\begin{array}{l}\text { LE, SPS, PERM, seizure, CA, } \\
\text { oculomotor dysfunction, } \\
\text { diabetes }\end{array}$ & $\begin{array}{l}<15 \% \text { (higher with } \\
\text { coexisting Abs, esp. } \\
\text { GABA-BR Ab) } \\
\text { lung, thymoma }\end{array}$ & $\begin{array}{l}\mathrm{T} 2 \text { mesiotemporal } \\
\text { hyperintensity }\end{array}$ & $\begin{array}{l}70 \% \text { had partial } \\
\text { improvement with } \\
\text { immunotherapy }\end{array}$ \\
\hline \multicolumn{5}{|c|}{ Intracellular } \\
\hline Ma & $\begin{array}{c}\text { LE, BE, diencephalic } \\
\text { encephalitis, seizure, CS }\end{array}$ & $\begin{array}{c}90 \% \\
\text { testicular, lung and pleural }\end{array}$ & Nonspecific & $\begin{array}{l}\text { Favorable in anti-Ma2 but } \\
\text { poorer in anti-Ma }\end{array}$ \\
\hline $\mathrm{Hu}$ & $\begin{array}{l}\text { LE, CS, BE, dysautonomia, } \\
\text { sensory neuropathy }\end{array}$ & $\begin{array}{l}>90 \% \\
\text { SCLC }\end{array}$ & Nonspecific & Poor \\
\hline $\mathrm{Ri}$ & $\begin{array}{l}\mathrm{LE}, \mathrm{CS}, \mathrm{BE}, \mathrm{OMS} \text {, movement } \\
\text { disorders }\end{array}$ & $\begin{array}{c}>90 \% \\
\begin{array}{c}\text { woman-breast, man-lung } \\
\text { and bladder }\end{array}\end{array}$ & Nonspecific & $\begin{array}{c}\text { Common co-expression with } \\
\text { other Abs }\end{array}$ \\
\hline CRMP5 & $\begin{array}{l}\text { LE, encephalomyelitis, CS, } \\
\text { SPS }\end{array}$ & $\begin{array}{c}>90 \% \\
\text { SCLC, thymoma }\end{array}$ & $\begin{array}{c}\text { Normal or T2 mesiotemporal } \\
\text { hyperintensity }\end{array}$ & Poor \\
\hline SOX1 & $\begin{array}{l}\text { LE, LEMS, CS, neuropathy, } \\
\text { LEMS }\end{array}$ & $\begin{array}{l}30-60 \% \\
\text { SCLC }\end{array}$ & $\begin{array}{c}\text { Normal or T2 mesiotemporal } \\
\text { hyperintensity }\end{array}$ & $\begin{array}{c}\text { Common co-expression with } \\
\text { other Abs; poor response to } \\
\text { treatment }\end{array}$ \\
\hline AK5 & LE & No data & Hippocampal atrophy & Poor response to treatment \\
\hline
\end{tabular}

Abs: antibodies; AK5: adenylate kinase 5; AMPAR: $\alpha$-amino-3-hydroxy-5-methyl-4-isoxazolepropionate receptor; BE: brainstem encephalitis; CASPR2: contactin-associated protein-like 2; CRMP5: collapsin response-mediator protein-5; CNS: central nervous system; CS: cerebellar syndrome including paraneoplastic cerebellar degeneration; DPPX: dipeptidyl peptidase-like protein 6; FBDS: faciobrachial dystonic seizures; GABA-BR: $\gamma$-aminobutyric acid B receptor; GAD: glutamic acid decarboxylase; LE: limbic encephalitis; LEMS: LambertEaton myasthenic syndrome; LGI1: leucine-rich, glioma inactivated 1; mGluR5: metabotropic glutamate receptor subtype 5; OMS: opsoclonus-myoclonus syndrome; PERM: progressive encephalomyelitis with rigidity and myoclonus; SCLC: small-cell lung cancer; SE: status epilepticus; SOX1: sex-determining region Y (SRY)-box 1; SPS: stiff-person syndrome. 

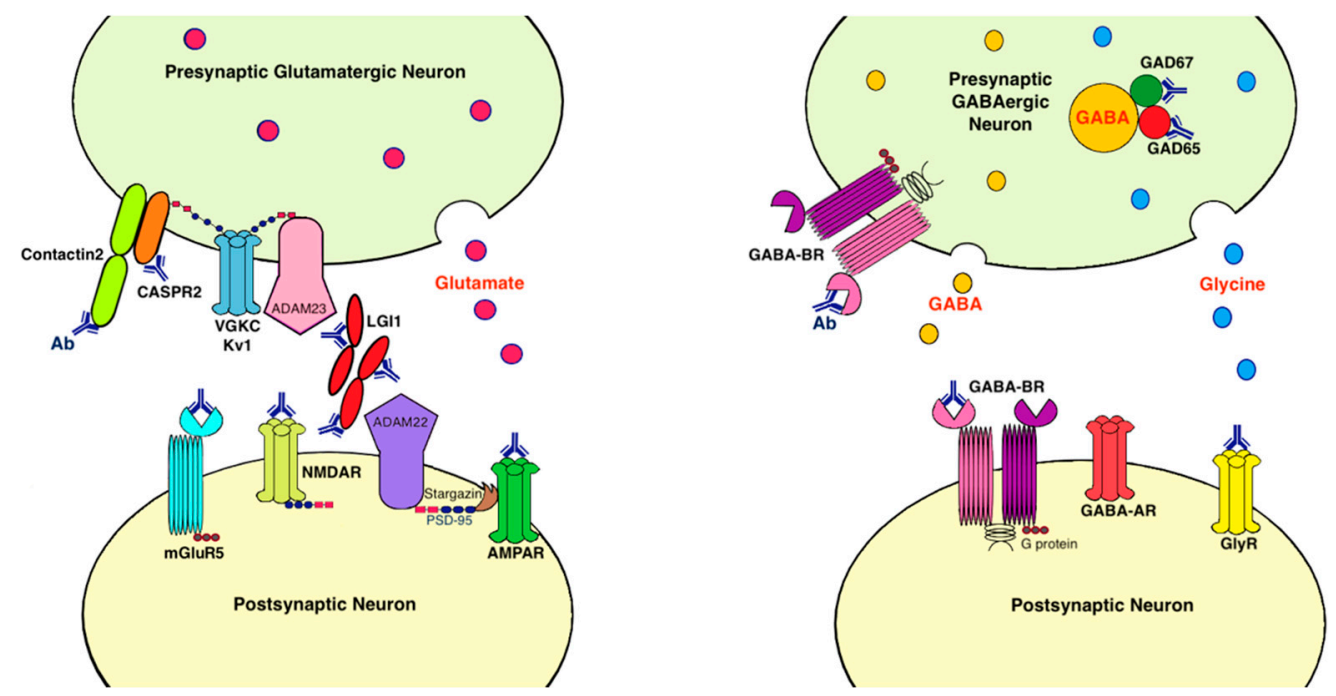

Figure 1. Antibodies and their pathogenic effects in limbic encephalitis. The pathologic effects of antibodies include blocking of receptors or ion channels, disruption of interaction with neighboring molecules, and crosslinking and internalization of receptors from cell surface. (1) CASPR2 and contactin2 antibodies inhibit the interaction between these proteins and reduce the clustering and surface expression of VGKC; (2) LGI1 antibody disrupts interaction between protein components such as LGI1 to ADAM22/23, downregulates VGKC and reduces AMPAR clustering and synaptic transmission; (3) AMPAR antibody causes cross-linking and receptor internalization; (4) NMDAR* antibody causes cross-linking and receptor internalization; (5) mGluR5 antibody causes decreased synaptic mGluR5 cluster density; (6) GAD antibodies target mostly the GAD65 subunits but also the GAD67 subunits, disrupting GABAergic signaling; (7) GABA-BR antibody prevents ligand binding to the receptor and alters receptor function; (8) GlyR antibody probably acts as antagonist to disrupt receptor function. Ab: antibody; ADAM: a disintegrin and metalloproteinase; AMPAR: $\alpha$-amino-3-hydroxy-5-methyl-4isoxazolepropionate receptor; CASPR2: contactin associated protein-like 2; GABA-AR: $\gamma$-aminobutyric acid-A receptor; GABA-BR: $\gamma$-aminobutyric acid-B receptor, GAD: glutamic acid decarboxylase; GlyR: glycine receptor; LGI1: leucine-rich, glioma inactivated 1; mGluR5: metabotropic glutamate receptor 5; NMDAR: N-methyl-D-asparate receptor; PSD-95: postsynaptic density protein 95; VGKC: voltage-gated potassium channels.

Antibodies may activate complements and natural-killer (NK) cells to induce complementdependent cytolysis or antibody-dependent cell-mediated cytotoxicity, resulting in neuronal death. The cell-surface and synaptic antibodies alter neurotransmission leading to neuronal dysfunction, whereas intracellular antibodies are epiphenomenon of T-cell-mediated immune response rather than direct pathogenic mediators of neurological diseases. Intracellular (onconeural) antibodies are considered biomarkers for the presence of tumors [22,23]; therefore, aggressive tumor survey is necessary. Removal of tumors is mandatory to ameliorate PNS and enhance treatment response. Nevertheless, intracellular antibodies can be detected in patients without identifiable tumors or with cancer without PNS [24].

LE with cell-surface and synaptic antibodies can also be triggered by cancer, although this association has lower frequency. The most common antibodies affecting the limbic system are antibodies against LGI1, GAD, GABA-BR, AMPAR, CASPR2, Ma2, and Hu [11,25]. A latest systemic review comprising 24 studies with 263 Asian patients with LE showed that $53 \%$ had LGI1, 43\% had GABA-BR, and $4 \%$ had CASPR2 antibodies [26]. About 7\% of patients with LE were seronegative [11]. Rarely, $\geq 2$ autoantibodies coexist in the same patient. Patients with LE having double or triple antibodies have worse outcomes than those with single antibody because of a higher chance of concomitant tumors [27-29].

In addition, patients with LE may have other comorbid autoimmune diseases, which should also be evaluated and treated. For example, about half of patients with Hashimoto encephalopathy had anti-NH2-terminal of $\alpha$-enolase antibodies, and some manifested as LE [30]. 


\section{Immunopathology}

LE with antibodies against cell-surface antigens act mainly through antibody and/or complement-mediated mechanisms. However, LE with antibodies against intracellular antigens is predominantly mediated by cluster of differentiation (CD) 8+ cytotoxic T cells with frequent neuronal loss $[17,25]$. T cells are the major immune cells in the CSF, which play a major immunosurveillance role in the central nervous system (CNS) [31]. In all AE cases, CD3+ lymphocytes comprised the majority of inflammatory cells within the brain. A significant difference in the proportion of parenchymal CD8+ T cells $(\mathrm{CD} 8 / \mathrm{CD} 3$ ratio) between intracellular and surface antibodies (mean $75 \%$ vs. $43 \%$, respectively) was noted. The percentage of CD8+ T cells in the GAD antibody-mediated disease is intermediate (54\%) [17]. The CD8+ T cells cause impairment of neuronal excitability and integrity with neuronal degeneration via two independent pathways: (1) granule cytotoxicity by perforin and granzyme-B and (2) ligation of death receptors [32,33]. Perforin is a $\mathrm{Ca}^{2+}$ dependent protein, which can form transmembranous pores, alter electrical excitability and signaling, and cause neuronal necrosis with swelling and rupture of cell membranes. Perforin mediates the delivery of granzymes into the target cells to promote apoptosis [34]. Apposition of multiple granzyme-B lymphocytes to single neurons, which is consistent with a specific cytotoxic T-cell attack, was observed in several onconeural antibody-mediated diseases. Therefore, higher CD8/CD3 ratio and more frequent appositions of granzyme-B+ cytotoxic $\mathrm{T}$ cells to neurons were associated with greater neuronal loss [17]. Cytotoxic $\mathrm{T}$ cells can also liberate neurotoxic cytokines, such as interferon- $\gamma$ (IFN- $\gamma$ ) and tumor necrosis factor- $\alpha$ as well as excitotoxic glutamate [35]. CD8+ T cells also destroy the myelin sheath or glial cells in both white and gray matter [32].

In addition to antibodies and lymphocytes, microglia and astrocytes also play roles in mediating neuronal damages in the hippocampus and other brain regions. Microglia and astrocytes are required for synaptic integrity structurally and synaptic transmission functionally [36]. Activated microglia have dual functions, either anti-inflammatory or proinflammatory [37]. Previous studies showed that activated microglia in hippocampus may be associated with chronic epilepsy and was also found in VGKC-associated LE [38-40]. Immunotherapy may decrease the activation of microglia leading to improvement in seizure. Astrocytes and their autoimmune glial fibrillary acidic protein (GFAP) have also been shown to be associated with AE including NMDAR encephalitis and other encephalitis mimicking LE [41,42], and play important roles in neuroinflammation. The activation of astrocytes may trigger an astrocyte-neuron signaling cascade leading to persistent functional change in hippocampal excitatory synapses [43], which may be associated with cognitive impairment.

\section{Inflammatory Mediators}

Conventional CSF inflammatory markers such as white blood cells or protein are neither sensitive nor specific for LE, although the detection of oligoclonal band may increase diagnostic sensitivity [44]. A lower CD4/CD8+ T-cell ratio is detected in the CSF of all patients with LE [45].

The serum and CSF levels of C-X-C motif chemokine ligand 13 (CXCL13) were significantly higher in patients with LGI1 encephalitis [46]. The serum levels of CXCL10 were elevated in CASPR2 encephalitis. CXCL10 is a cytokine that recruits C-X-C motif chemokine receptor 3 cells such as activated T cells [47]. CASPR2 encephalitis seems to elicit a higher immune response than LGI1 encephalitis, with more intrathecal IgG and higher cytokine levels, indicated by higher CXCL13 and soluble intercellular adhesion molecule-1 (sICAM1) in the CSF. CXCL13 points to a B-cell mediated, whereas sICAM1 to a T-cell mediated neuroinflammation [48]. Patients with PNS also had high levels of chemokine CXCL10 in the CSF with the presence of IFN- $\gamma$ receptors on their T cells [47].

CSF mediators are different in infectious and immune-mediated encephalitis [49]. CSF cytokines IL-21 and IFN- $\gamma$-induced protein $10 \mathrm{kDa}$ (IP10) are promising in differentiating between viral encephalitis and AE [50]. IL-21 causes autoantibody production, which 
downregulates regulatory $\mathrm{T}$ cells leading to enhanced autoimmunity and increased CD8+ $\mathrm{T}$ cells and NK cells in AE [51], whereas IP10/CXCL10 is secreted in response to IFN- $\gamma$, which is produced as part of the Th1 in response to viral infection [52].

\section{Genetic Factors}

Human leukocyte antigen (HLA) is the main genetic factor related to autoimmunity. Anti-LGI1 encephalitis is strongly associated with HLA class II allele DRB1*07:01, which was carried by approximately $90 \%$ of patients, as well as $B^{*} 44: 03$ and $C^{*} 07: 06$ in the HLA class I allele [53,54]. DRB1*11:01 was detected in approximately $50 \%$ of the patients with CASPR2-antibody syndrome [54]. Anti-GAD neurological syndromes have frequent association with HLA class II haplotype DQA1*05:01-DQB1*02:01-DRB1*03:01 [55].

\section{Cancers}

Cancers occur in $20-60 \%$ of patients with LE $[11,56]$. LE can be classified as paraneoplastic or nonparaneoplastic, based on the presence or absence of an underlying malignancy [57].

Genetic alterations in tumor cells may trigger immune tolerance breakdown with initiation of PNS [58]. In PNS, the target antigens such as $\mathrm{Hu}, \mathrm{Ma}$, Yo, Ri, CRMP5, amphiphysin, and SOX-1 are proteins normally expressed by neurons and expressed ectopically by tumor cells. These antigens are recognized by onconeuronal antibodies or presented to $\mathrm{T}$ cells, which result in both cellular and humoral immune responses against neural structures $[3,59]$. The most common PNSs are LE and cerebellar degeneration, each accounting for approximately one-third of all PNSs [60]. Lung cancer, particularly small cell lung cancer (SCLC), testicular germ-cell tumor, thymoma, and lymphoma are the most frequent associated tumors [60-62]. Almost all patients with LE caused by $\mathrm{Hu}$ antibodies have SCLC [22]. Approximately $60 \%$ of patients with neurological syndromes associated with GABA-BR antibodies have underlying SCLC, and $60 \%$ of those with AMPAR antibodies have non-SCLC, breast cancer, or thymic tumors [63]. The presence of tumor is rare in patients with VGKC antibodies, especially LGI1 antibody, but is more common in patients with peripheral nervous system involvement such as Morvan syndrome or neuromyotonia caused by CASPR2 antibody. In the latter condition, a thymoma is common [64,65]. Therefore, screening for malignancy is usually required in patients with LE because the coexistence of tumors and their treatment influence the clinical outcome [61]. If initial tumor screening is negative, total-body FDG-PET is recommended [16], or screening can be repeated after 3-6 months, followed by screenings every 6 months for 4 years [66].

\section{Infection}

Occurrence of AE during the convalescence phase of viral CNS infections, particular NMDAR encephalitis after herpes simplex encephalitis (HSE), has been well-known [67]. Patients with HSE may also develop antibodies to GABA-BR, AMPAR, dopamine-2 receptors, or concurrently to NMDAR and LGI1, and manifest relapses of neurologic symptoms $[2,68,69]$. Proposed mechanisms include (1) induction of self-immunization due to a viral-induced inflammatory response leading to the release of neural tissue epitopes such as NMDAR and (2) molecular mimicry based on sequence homology or structural similarities between viral protein and neural tissue epitopes [20,70]. Human herpesvirus 6 was reported as a cause of LE in immunocompromised hosts after hematopoietic stem cell transplant [71] or triggering factor of GABA-BR encephalitis [2].

\section{Immune Checkpoint Inhibitors}

In addition to developing PNS, patients with cancers receiving biological cancer therapies with ICI's are at risk for developing peripheral and CNS complications [72,73]. The main ICI's are ipilimumab targeting the cytotoxic T-lymphocyte antigen 4 and pembrolizumab and nivolumab inhibiting the programmed cell death 1 pathway [74]. LE is the most frequent CNS complication of ICI's [73]. Antibody-positive (CASPR2, Hu, 
Ma2, and GAD65 antibodies) or antibody-negative LE may develop weeks to 1 year after starting ICI's therapy [75-78]. Anti-Ma2 antibody is the most common antibody found in ICI-induced LE, which carries a poor outcome [73].

\section{Antigens Associated with LE}

\subsection{Voltage-Gated Potassium Channel Complex (VGKC)}

VGKCs are located on the neuronal membranes of both the central and peripheral nervous system. The VGKC complex is composed of Kv1 subunits, which function with other extracellular proteins including LGI1, CASPR2, and contactin 2, membranous proteins a disintegrin and metalloproteinase 22 and 23 (ADAM22 and 23), and intracellular scaffolding proteins including postsynaptic density protein 95 (PSD-95) [79]. VGKC antibody is categorized into four subgroups: LGI1 positive, CASPR2 positive, VGKC-positive group lacking both LGI1 and CASPR2 antibodies (double-negative VGKC) [19], and rarely double positive group [8]. The extracellular proteins LGI1 and CASPR2 are direct antigenic epitopes of VGKC antibodies, whereas in double-negative VGKC, antibody may target another extracellular protein, the contactin-2 or intracellular epitopes [80]. VGKC antibodies cause VGKC hyperexcitability spectrum, including LE, Morvan syndrome, neuromyotonia (Isaacs' syndrome), seizures, sleep disturbance, and autonomic dysfunction [81,82]. Patients with VGKC complex LE were more likely to have an autoimmune inflammation than patients with other syndromes [83], and may show perivascular lymphocytic infiltration and neuronal loss predominantly in the hippocampus and amygdala [38]. A complement-mediated neuronal death may play a prominent role [17]. A positive VGKC antibody, especially if tested by radioimmunoprecipitation assay, has uncertain pathogenicity and limited clinical specificity [8,84]. Testing LGI1 and CASPR2 antibodies separately is advocated instead of testing VGKC antibody alone [85].

\subsection{Leucine-Rich, Glioma Inactivated 1 Protein (LGI1)}

LGI1 is a secreted synaptic protein, which interacts with presynaptic and postsynaptic ADAM to form a trans-synaptic linkage between presynaptic ADAM23-Kv1 channel and postsynaptic ADAM22-PSD-95. LGI1 is important for AMPAR-mediated synaptic transmission [86]. LGI1 is located mainly in the hippocampus and temporal cortex, and the LGI1-ADAM22-AMPAR interaction influences both long-term depression (LTD) and long-term potentiation (LTP) [87]. LGI1 secreted from the excitatory pyramidal neurons contributes to LGI1-related epileptogenesis [88]. LGI1 antibodies inhibit binding of LGI1 to ADAM22/23, downregulate Kv1.1, reduce AMPAR clustering, and alter synaptic excitability, plasticity, and memory $[89,90]$. Faciobrachial dystonic seizures are very specific for LGI1-encephalitis, but only present in about $50 \%$ of patients [91]. One-third of patients had peripheral nervous system manifestations, commonly with pain and dysautonomia [8]. Comorbid tumors (mainly thymoma and SCLC) [92] occurred in $<10 \%$ of patients with anti-LGI1 LE.

\subsection{Contactin-Associated Protein-Like 2 (CASPR2)}

CASPR2 is a transmembrane cell adhesion protein of the neurexin family that is located at the juxtaparanodal region of the nodes of Ranvier in myelinated axons of the central and peripheral nervous system. CASPR2 interacts with dimerized contactin-2 (also known as transient axonal glycoprotein-1) [93,94] and colocalizes with VGKC Kv1.1 and Kv1.2 [95]. CASPR2 antibodies do not reduce CASPR2 expression but inhibit the interaction of CASPR2 with its binding partner contactin 2 [96] and reduce the clustering and surface expression of Kv1, thereby interfering with axonal excitability and action potential conduction [93,97]. CASPR2 antibodies did not cause evident neuronal loss, except for a modest Purkinje cell loss in the cerebellum [12].

CASPR2 antibody-associated diseases almost exclusively affect older males. $80 \%$ of patients have neuropsychiatric features such as cognitive deficits, and 50\% developed seizures. Many others presented with neuropathic pain associated with peripheral neuronal 
hyperexcitability such as myokymia, fasciculations, and muscle cramps [19,98]. Other syndromes include autonomic dysfunction, cerebellar symptoms, insomnia, or weight loss [19]. Cancer is more frequent in CASPR2 compared to LGI1-antibody positive patients, more commonly with thymoma [8].

\subsection{AMPA Receptor}

AMPARs are glutamatergic ionotropic transmembrane receptors composed of four subunits (GluA1-4) [99]. AMPARs are concentrated in the hippocampal CA3-CA1 region, subiculum, basal ganglia, cerebellum, and the cerebral cortex. They mediate most of the fast excitatory synaptic transmission in the brain and are critical for synaptic plasticity, learning, and memory [100]. LE patients' antibodies usually target GluA1 or GluA2 subunits of AMPARs, which decrease AMPAR clustering at synapses through increased internalization of receptors but do not alter the synaptic density or cell viability [101,102]. In accordance with the decrease in AMPA-mediated excitatory postsynaptic currants, affected neurons also exhibit homeostatic decrease in inhibitory postsynaptic currants and reduced inhibitory synapse density, whereas the intrinsic neuronal excitability increases [102]. AMPAR antibodies do not cause significant neuronal apoptosis. Synaptic AMPAR cluster density was restored within a few days after removal of patients' antibodies, and patients usually recovered to baseline after treatment [101].

In AMPAR encephalitis, confusion is the most frequent manifestation. Seizure occurs in approximately one-third of patients. Associated cancers were found in approximately $50-60 \%$ of patients, most commonly lung carcinoma and thymoma $[27,103]$.

\subsection{Metabotropic Glutamate Receptor 5 (mGluR5)}

Glutamate receptors (GluRs) are the main excitatory synaptic transmission mediators in the brain. GluRs can be divided into ligand-gated ion channels (ionotropic) and G protein-coupled (metabotropic) GluRs (mGluRs). In the three groups of mGluRs, mGluR5 belongs to group I. mGluR5 are expressed primarily in the hippocampus and amygdala, which modulates LTD and LTP [104]. mGluR5 antibodies cause a decrease of mGluR5 cluster density at both synaptic and extrasynaptic locations [105]

All patients with anti-mGluR5 encephalitis had CSF pleocytosis and 75\% had oligoclonal bands. MRI abnormalities revealed not only the limbic system involvement, but also the involvement of extralimbic regions such as thalamus, pons, frontal or parietooccipital cortex, and cerebellum [105]. mGluR5 antibody is associated with LE and Hodgkin lymphoma, presented as Ophelia syndrome in nearly $50 \%$ of patients $[105,106]$.

\subsection{Dipeptidyl Peptidase-Like Protein 6 (DPP6)/DPPX}

DPP6 (DPPX) is a membrane glycoprotein and an auxiliary subunit of the voltagegated A-type (rapidly inactivating) potassium channel Kv4.2 [107]. Kv4.2 is involved in somatodendritic signal integration and attenuation of back-propagation of action potentials [107], which is responsible for transient, inhibitory currents in the peripheral and CNS [108]. DPPX is predominantly expressed in the hippocampus, cerebellum, and striatum [109]. DPPX antibodies are predominantly of IgG4 subtype. Loss of DPPX modulation of potassium currents leads to neuronal hyperexcitability [108].

Most patients with DPPX encephalitis had a combination of LE, brainstem dysfunction, severe diarrhea, and weight loss $[107,110,111]$. Many patients have characteristic gastrointestinal symptoms even before neuropsychiatric symptoms [111] because of the enriched expression of DPPX in myenteric plexus [112]. The course of neuropsychiatric symptoms in anti-DPPX encephalitis was prolonged, and chronic immunotherapy is often required [107].

\subsection{GABA-B Receptor}

GABA-BRs are transmembrane G-protein-coupled receptors composed of two subunits, the GABA-B1 and GABA-B2, and mediate slow and prolonged inhibitory neuro- 
transmission [113]. GABA-BRs are ubiquitously distributed in the brain and spinal cord, but the highest levels are found in the hippocampus, thalamus, and cerebellum [114]. Most GABA-BR antibodies recognized the GABA-B1 subunit. GABA-BR antibodies do not decrease the synaptic levels of receptors but alter their synaptic function.

Co-expression of GABA-BR with other autoantibodies is relatively common [63,115-118]. Reported coexisting antibodies in GABA-BR encephalitis included potassium channel tetramerization domain containing 16 (KCTD16), GAD65, Hu, Ri, amphiphysin, SOX1, CV2/CRMP, 5N-type or P/Q-type voltage-gated calcium channels, or thyroid peroxidase $[115-117,119,120]$. Most of these cases were paraneoplastic.

Anti-GABA-BR encephalitis have highest rates for pleocytosis, protein concentration, and positive oligoclonal bands compared to other LE [121]. Increased CSF glutamate levels were found in GABA-BR associated encephalitis [122]. Increased CD138+ and CD19+ plasma cells and activated cytotoxic T cells in CSF corresponded to higher overall neuropsychological and memory deficits in patients with GABA-BR LE. A hippocampal specimen also revealed perivascular infiltrates of CD138+ plasma cells and CD4+ T cells, whereas cytotoxic CD8+ T cells were detected within the brain parenchyma in close contact to neurons [123].

Patients with GABA-BR LE had seizure, confusion, and memory deficits. $80-100 \%$ of patients presented an early or prominent seizure, and a large proportion had convulsive or nonconvulsive status epilepticus. Seizure was often of temporal lobe onset, usually refractory to medications but was well responsive to immunotherapy $[63,115,116,120]$. The seizure phase was followed by an encephalitic phase compatible with LE such as confusion and memory deficits. More than 50\% of patients had tumors, mostly SCLC $[115,116,124]$.

\subsection{Glutamic Acid Decarboxylase (GAD)}

GAD is a rate-limiting enzyme in presynaptic inhibitory neurons for synthesis of the inhibitory neurotransmitter GABA from glutamate, using pyridoxal-5' -phosphate as cofactors. GAD is widely distributed within the CNS and pancreas [125]. There are two isoforms: cytoplasmatic, a constitutively active isoform of $67 \mathrm{kDa}$ (GAD67) for maintaining steady basal production of GABA and synaptic membrane-associated form of $65 \mathrm{kDa}$ (GAD65), which undergoes auto-inactivation during enzyme activity and provides pulse production when rapid surge of GABA is required [126]. GAD65 is localized predominantly in nerve terminals, anchored to the cytoplasm-facing side of synaptic vesicles [127]. Compared with GAD67, GAD65 has greater antigenicity partly due to its surface electrostatic charge and greater mobility in the C-terminal and catalytic domains [127]. GAD is mostly found intracellularly but transiently exposed extracellularly during the dynamic process of neurotransmission and exocytosis [128].

GAD antibodies disrupt GABAergic signaling. GAD65 antibodies are detected in about $8 \%$ of general population, but always at low level [129]. GAD antibodies are frequently found in patients with type 1 diabetes mellitus (DM1) (80-90\%), and around $40 \%$ of patients had been diagnosed with DM1 before the onset of neurologic symptoms $[125,130]$. Patients with neurologic syndromes associated with GAD usually have serum titers several hundred-fold higher than those with DM1 [131]. GAD antibodies from patients with DM1 did not react with brain tissue [132]. In rats, in vivo injection of GAD65 antibodies from patients with stiff-person syndrome (SPS) induced electrophysiologic changes in myelinated neurons, whereas GAD65 antibodies from patients with DM1 did not [133]. Antibodies seem to recognize different GAD65 epitopes in patients with DM1 and neurologic syndromes [134]. Pathological specimens showed T-cell infiltrates but no IgG deposition as well as acute necrosis and neuronal loss in the hippocampus, evolving to hippocampal atrophy [17,135]. Loss of GABAergic neurons in the brainstem has been observed [136].

Most patients harboring GAD65 antibodies are women, with a mean age of 23 years, which is younger compared to LE caused by other antibodies. According to one small pediatric case series of LE, $50 \%$ of patients had GAD antibodies [137]. Neurological syndromes associated with GAD antibodies include SPS, cerebellar ataxia, limbic and extralimbic 
encephalitis, nystagmus/oculomotor dysfunction, drug-resistant epilepsy, paraneoplastic SPS, and progressive encephalopathy with rigidity and myoclonus. The latter two are mainly related to amphiphysin and glycine receptor antibodies, respectively [138]. Seizures occurred in almost all patients with GAD-related LE, may present as status epilepticus, and were difficult to control even with immunotherapy [139-141].

GAD antibodies were detected in $7-17 \%$ of adult patients with LE [135]. Previous study reported a probable $<15 \%$ cancer association in GAD antibody-associated LE [135]. GAD antibody-associated LE is ten times more likely to be paraneoplastic than other neurologic syndromes such as SPS or cerebellar ataxia. The most frequent tumors are lung and thymic neoplasms. Patients with PNS associated with GAD were older, male predominance, having coexisting antibodies than non-neoplastic GAD cases $[116,119,142]$. Cancer risk is seven times higher in patients with GAD and coexisting antibodies against neuronal cell-surface antigens, especially GABA-BR [119]. The prognosis varies and is considered intermediate between that of neurologic syndromes associated with antibodies against cell-surface and intracellular antibodies [138]. Approximately $70 \%$ of patients with high GAD65 antibody concentration improved partially after immunotherapy; however, none reached a complete recovery [130].

\section{Intracellular Antibodies}

Intracellular antigens such as Ma, Hu, Ri, Yo, CRMP5, amphiphysin, or SOX1 are considered inaccessible by their antibodies [143]. Intracellular antibodies are usually considered onconeural antibodies due to their strong association with tumors. Anti-Hu antibodies were the most frequently detected antibodies in PNS associated with onconeural antibodies. Cerebellar degeneration was the most frequent syndrome in PNS associated with onconeural antibodies, whereas brainstem encephalitis and subacute sensorimotor neuronopathy were the most frequent nonclassical syndromes [144]. LE is a rare neurologic presentation in this entity. Onconeural antibodies associated with paraneoplastic LE are $\mathrm{Ma}, \mathrm{Hu}, \mathrm{Ri}, \mathrm{CRMP} 5$, and SOX1 $[66,145]$, with Ma2 being the major intracellular antibody causing paraneoplastic LE [146]. In paraneoplastic LE associated with lung cancer, Hu and cell surface GABA-BR antibodies were the most frequently encountered antibodies, whereas in paraneoplastic LE associated with testicular tumor, Ma2 antibody is the most frequent antibody $[147,148]$.

\section{Treatment}

\subsection{First-Line Treatment}

First-line treatment (Table 2) includes pulse therapy with intravenous methylprednisolone, intravenous immunoglobulin (IVIg), or plasmapheresis. Methylprednisolone is usually given first, followed by either IVIg or plasmapheresis within 3-7 days depending on clinical features and disease severity [16].

Although IVIg and plasmapheresis neutralize or eliminate systemic antibodies, they do not target plasma cells or intrathecal antibody synthesis. Both plasma exchange (PE) and immunoadsorption (IA) resulted in clinical improvement in $60-67 \%$ in patients with AE associated with NMDAR, LGI1, CASPR2, mGluR5, GAD, and Hu antibodies [149-151]. Plasmapheresis was more effective for encephalitis caused by cell-surface antigens (approximately 85\%) than by intracellular or synaptic antigens (66.7\%) [149-151]. Response rate was higher with early initiation of therapy [152].

In patients with encephalitis after ICI's treatment, early immunotherapy with steroids or IVIg is essential [153]. 
Table 2. Immunotherapy for limbic encephalitis.

\begin{tabular}{|c|c|c|c|}
\hline & Dose \& Duration & Mechanism & Note \\
\hline \multicolumn{4}{|c|}{ First Line } \\
\hline Methylprednisolone & $\begin{array}{l}\text { Adult: } 1 \mathrm{~g} \text { daily } \\
\text { Children: } 30 \mathrm{mg} / \mathrm{kg} / \text { day } \\
\text { (max. } 1 \mathrm{~g}) \\
\text { for } 3-5 \text { days }\end{array}$ & $\begin{array}{l}\text { Inhibits NF-кB } \rightarrow \\
\text { anti-inflammation }\end{array}$ & $\begin{array}{l}30 \mathrm{mg} / \mathrm{kg} / \text { day }(\max .1 \mathrm{~g} \text { ) once } \\
\text { monthly for } 3-6 \text { months }\end{array}$ \\
\hline IVIg & $2 \mathrm{~g} / \mathrm{kg}$ in 2 or 5 days & $\begin{array}{l}\text { Neutralizes Abs and cytokines, } \\
\text { decreases B cells, inhibits } \\
\text { complement activation, } \\
\text { modulates regulatory T cells }\end{array}$ & $\begin{array}{c}1 \mathrm{~g} / \mathrm{kg} \text { monthly for } 3 \text { months or } \\
\text { longer } \\
\text { Should not be given immediately } \\
\text { prior to plasmapheresis }\end{array}$ \\
\hline $\begin{array}{l}\text { Plasmapheresis } \\
\text { (PE or IA) }\end{array}$ & 5-7 exchanges in 10-14 days & Remove $\mathrm{Ab}$ & \\
\hline \multicolumn{4}{|c|}{ Second Line } \\
\hline Rituximab & $\begin{array}{l}375 \mathrm{mg} / \mathrm{m}^{2} \text { weekly for } 4 \text { weeks, or } \\
750 \mathrm{mg} / \mathrm{m}^{2} \text { (max. } 1000 \mathrm{mg} / \text { dose) } \\
\text { for two doses } 2 \text { weeks apart }\end{array}$ & $\begin{array}{l}\text { Anti-CD20 Ab } \rightarrow \text { depletion of } \\
\text { B cells and plasmablasts }\end{array}$ & \\
\hline Cyclophosphamide & $\begin{array}{c}750-1000 \mathrm{mg} / \mathrm{m}^{2} \\
\text { (max. } 1000-1500 \mathrm{mg} / \text { dose) } \\
\text { monthly for } 3-6 \text { months }\end{array}$ & $\begin{array}{c}\text { Akylating agents inhibiting DNA } \\
\text { synthesis } \rightarrow \text { suppress B and } \\
\text { T cells }\end{array}$ & Cause infertility in repeated doses \\
\hline Tocilizumab & $\begin{array}{l}\text { 8-12 mg/kg (max. } 800 \mathrm{mg} \text { ) } \\
\text { monthly for } 6 \text { months }\end{array}$ & $\begin{array}{c}\text { Anti-IL6 receptor } \mathrm{Ab} \rightarrow \text { inhibits } \mathrm{B} \\
\text { and } \mathrm{T} \text { cells }\end{array}$ & \\
\hline Daratumumab & $\begin{array}{l}16 \mathrm{mg} / \mathrm{kg} \text { weekly in cycle } 1-8, \\
\text { every two weeks in cycle } 9-13\end{array}$ & $\begin{array}{l}\text { anti-CD38 } \mathrm{Ab} \rightarrow \text { depletion of } \\
\text { plasma cells }\end{array}$ & $\begin{array}{l}\text { One case of anti-CASPR2 } \\
\text { encephalitis }\end{array}$ \\
\hline Bortezomib & $\begin{array}{l}1.3 \mathrm{mg} / \mathrm{m}^{2} \text { on day } 1,4,8, \text { and } 11 \\
\text { of a } 21 \text {-day cycle, total } 3 \text { cycles }\end{array}$ & $\begin{array}{c}\text { proteasome inhibitor } \rightarrow \text { depletion } \\
\text { of plasma cells }\end{array}$ & Clinical trial (NCT03993262) \\
\hline \multicolumn{4}{|c|}{ Maintenance therapy } \\
\hline Prednisolone & $\begin{array}{l}1-2 \mathrm{mg} / \mathrm{kg} / \text { day once daily or } \\
\text { divided for } 4 \text { weeks; tapered over } \\
\text { several weeks to months }\end{array}$ & $\begin{array}{l}\text { Inhibits NF- } \mathrm{KB} \rightarrow \\
\text { anti-inflammation }\end{array}$ & \\
\hline Mycophenolate mofetil (MMF) & $\begin{array}{c}\text { Initial } 300 \mathrm{mg} / \mathrm{m}^{2} / \text { day, target } \\
600 \mathrm{mg} / \mathrm{m}^{2} / \text { day, } 1-1.5 \mathrm{~g} / \text { day, } \\
\text { twice daily }\end{array}$ & $\begin{array}{c}\text { Inhibits purine nucleotides } \rightarrow \\
\text { inhibits B and T cells }\end{array}$ & \\
\hline Azathioprine (AZA) & $\begin{array}{c}1-2.5 \mathrm{mg} / \mathrm{kg} / \text { day } \\
\text { (max.150 mg/day), once daily }\end{array}$ & $\begin{array}{l}\text { Inhibits purine synthesis } \rightarrow \\
\text { inhibits B and T cells }\end{array}$ & \\
\hline Methotrexate (MTX) & $\begin{array}{c}\text { Oral: } 10 \mathrm{mg} / \mathrm{m}^{2} \text { weekly } \\
\text { Intrathecal: } 10 \mathrm{mg} \text { weekly for } \\
4 \text { weeks }\end{array}$ & $\begin{array}{l}\text { Inhibits NF- } \mathrm{kB} \rightarrow \\
\text { anti-inflammation }\end{array}$ & \\
\hline
\end{tabular}

\subsection{Second-Line Treatment}

Second-line treatment includes rituximab, cyclophosphamide, azathioprine, mycophenolate mofetil (MMF), or others. It is usually started within approximately 2 weeks when the first-line therapies fail to achieve improvement $[19,154]$, or when the disease is severe or relapsing.

Rituximab and cyclophosphamide are the preferred second-line treatment. Rituximab is a monoclonal antibody targeting the CD20 expressed by B cells and plasmablasts. The lifetime of antibody-producing plasma cells is typically days to weeks [155], which accounts for the delayed response of rituximab [156]. In LE with common relapses such as AMPAR encephalitis, administration of second-line therapy resulted in less relapse [157]. Encephalitis caused by DPPX usually require rituximab [111].

Cyclophosphamide, a deoxyribonucleic acid alkylating agent, targets hematopoietic cells [158], which can cross the BBB and affects both B and T cells as well as the intrathecal antibody synthesis. In GAD-associated refractory status epilepticus, cyclophosphamide resulted in seizure control and decreased intrathecal production of antibody [159]. Both rituximab and cyclophosphamide target the antibody source, causing fewer relapses, and can be combined in most severe cases. However, combination therapy carries risks of 
progressive multifocal leukoencephalopathy or reactivation of infections such as hepatitis B [160].

Tocilizumab is an anti-IL-6 receptor monoclonal antibody. IL-6 is a key mediator for the survival of plasmablasts and plasma cells. IL-6 not only induces B-cell differentiation and proliferation, but also promotes the differentiation of IL-17-producing helper $\mathrm{T}$ cells and cytotoxic T cells $[161,162]$. For patients with AE having inadequate clinical response to the first-line therapy and rituximab, tocilizumab had been used with favorable outcome. Nearly $90 \%$ of the tocilizumab-treated patients maintained a long-term favorable clinical response [163]. Tocilizumab also resulted in improvement in LE cases caused by CASPR2 antibodies [164] and in pediatric case of AE caused by GAD antibodies refractory to first-line treatment [165].

Daratumumab, an anti-CD38 antibody that depletes plasma cells and modifies various T-cell functions, was used in a refractory case of CASPR2 encephalitis. Daratumumab resulted in antibody titers reduction, T-cell activation markers normalization, and neurological improvement. However, the reported patient died of septicemia [166].

Bortezomib, a proteasome inhibitor that interferes with NF- $\mathrm{KB}$ and ubiquitin-proteasome pathway to deplete plasma cells, is currently under clinical trial for patients with severe AE (NCT03993262).

\subsection{Maintenance Therapy}

Very limited evidence on the efficacy of long-term therapy were reported. In cases unresponsive to first or second-line immunotherapy, or in cases with relapses requiring maintenance therapy, drugs such as azathioprine, mycophenolate mofetil (MMF), or methotrexate can be utilized [167].

Monthly intravenous or oral steroid pulses, oral steroids with tapering dose, monthly IVIg, or rituximab redosing could also be tried [168]. In patients with LE having high relapse rates such as those with LGI1 and CASPR2 antibodies, a gradual corticosteroid tapering over around 18 months can decrease relapses [169].

In general, LE associated with cell-surface antibodies are more likely to respond to immunotherapy, resulting in good recovery in up to $70-80 \%$ of cases [56]. In PNS caused by onconeural antibodies, the tissue damage is thought to be primarily cell-mediated; therefore, immunotherapy often has only little effect. The most important treatment is prompt and complete removal of tumor in order to withdraw the auto-antigen expressed by the tumor that triggers the production of autoantibodies [61]. In treatment-resistant cases, gradual neuronal loss and brain atrophy were noted [25]. For these cases, if initial tumor screening is negative, tumor surveillance must be continued at follow-up, particularly depending on the antibody [16]. In addition to intracellular antibodies, certain cell-surface antibodies (e.g., AMPAR, GABA-BR, and mGluR5) are more often associated with tumors. If antibodies are not found and the clinical presentation fulfills the criteria of LE, screening with computed tomography of the thorax is recommended, followed by a total-body FDGPET [11]. In LGI1 patients, seizure including FBDS usually improved after immunotherapy. However, a large proportion $(60 \%)$ of GAD-LE patients was not seizure free.

\section{Prognosis}

The general mortality rate of LE was $9.7 \%$, largely due to pulmonary infection or status epilepticus. GABA-BR antibody was attributed to the highest mortality rate (23.2\%), largely due to tumor progression [26]. Cognitive dysfunction is a major complication in patients with long-term LE, and some patients are left disabled [56]. In LE caused by GAD, LGI1, or CASRP2 antibodies, the memory outcomes were poor even after clinical recovery with immunotherapy. Pathologic tearfulness was reported in 50\% of patients, which correlated with changes in certain emotional brain networks, although not part of the neuropsychiatric comorbidities [170]. 


\section{Conclusions}

The majority of patients with LE have prominent neuropsychiatric symptoms at disease onset, which is quite common in clinical practice. Therefore, patients with acute or subacute neuropsychiatric symptoms with the core symptom of memory deficits, particularly if associated with seizures or abnormal signal changes on brain MRI, particularly in the mesiotemporal region, should be highly suspected for LE (Figure 2 and Table 3). A diagnosis of LE is extremely important because timely immunotherapy is even more important than symptomatic therapies with antipsychotic or antiepileptic drugs, because partial or complete remission or even cure can be achieved.

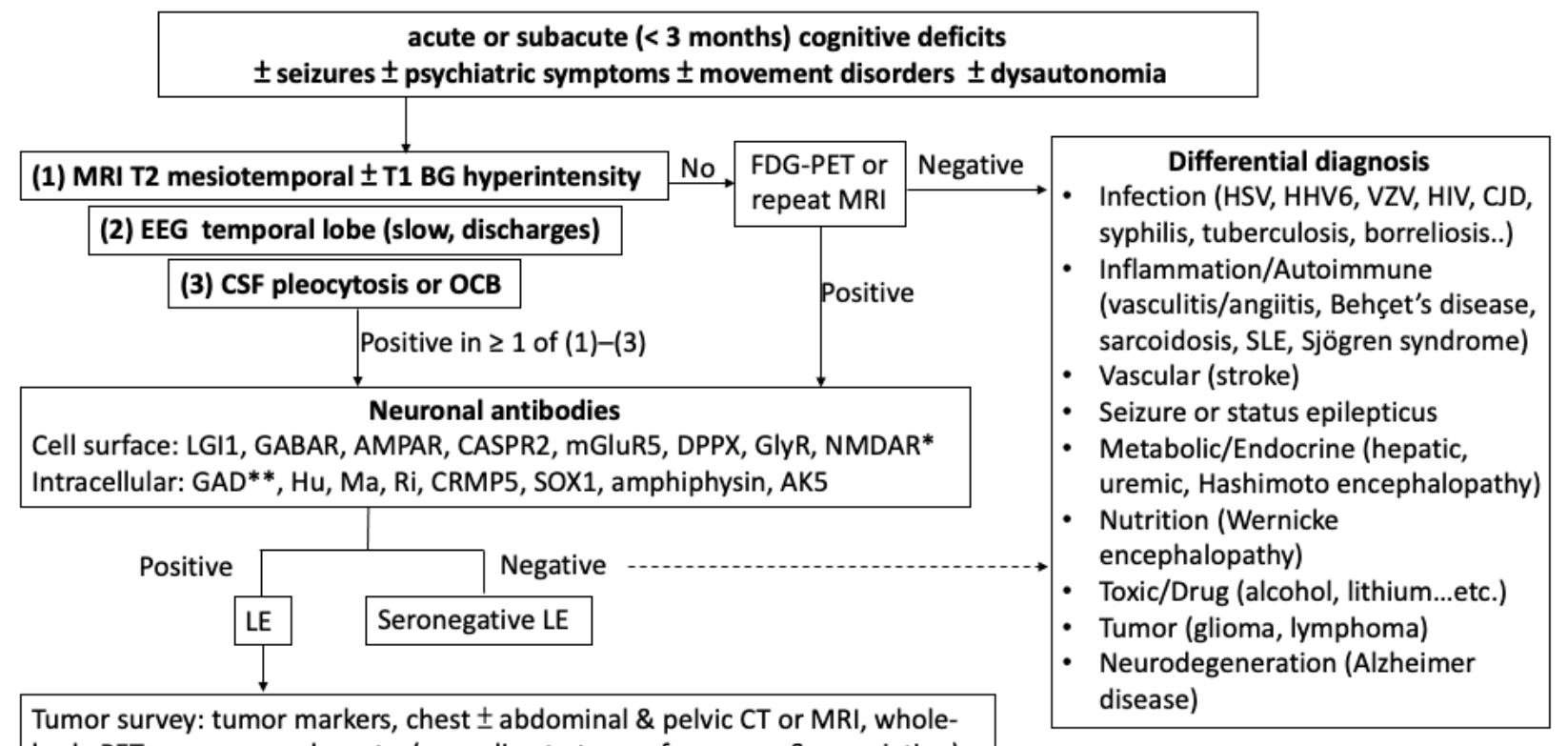

body PET, mammography...etc. (according to tumor frequency \& association)

Figure 2. Diagnostic algorithm of limbic encephalitis. NMDAR antibody $\left({ }^{*}\right)$ generally causes autoimmune encephalitis but rarely causes limbic encephalitis. Nevertheless, it should be included in neuronal antibody survey for limbic encephalitis due to clinical similarity. GAD $\left({ }^{* *}\right)$ is a synaptic enzyme.

Table 3. Characteristic symptoms and laboratory findings of limbic encephalitis.

\begin{tabular}{|c|c|}
\hline Symptoms & Antibodies \\
\hline Seizure & $\begin{array}{c}\text { GABA-BR }(\sim 100 \%), \text { LGI1 }(80-100 \%), \text { GAD }(60-100 \%), \\
\text { CASPR2 (75\%), NMDAR }{ }^{*}(70 \%), \text { AMPAR }(33 \%) \\
\text { FBDS in LGI1 }(33-67 \%)\end{array}$ \\
\hline Paroxysmal dizzy spells & LGI1 $(14 \%)$ \\
\hline Cramps or neuropathic pain & CASPR2, LGI1 \\
\hline Movement disorders & $\begin{array}{c}\text { NMDAR * CRMP5, Hu, GlyR, GABA-BR, DPPX, CASPR2, } \\
\text { Ri }\end{array}$ \\
\hline $\begin{array}{c}\text { Dysautonomia } \\
\text { GI symptoms (diarrhea) }\end{array}$ & $\begin{array}{c}\text { NMDAR * LGI1, CASPR2, GABA-BR, DPPX, GlyR } \\
\text { DPPX }\end{array}$ \\
\hline Laboratory findings & Antibodies \\
\hline Hyponatremia & GLI1 ( 50\%), CASPR2 ( 25\%) \\
\hline Hyperglycemia & GAD \\
\hline CSF pleocytosis $+\mathrm{OCB}$ & GABA-BR, GAD, mGluR5 \\
\hline
\end{tabular}

NMDAR antibody $\left({ }^{*}\right)$, a frequently detected antibody in autoimmune encephalitis, should also be included in antibody survey for limbic encephalitis due to clinical similarity. AMPAR: $\alpha$-amino-3-hydroxy-5-methyl-4isoxazolepropionic acid receptor; CASPR2: contactin-associated protein-like 2; CSF: cerebrospinal fluid; DPPX: dipeptidyl peptidase-like protein 6; FBDS: faciobrachial dystonic seizures; GABA-BR: $\gamma$-aminobutyric acid B receptor; GAD: glutamic acid decarboxylase; GI: gastrointestinal; GlyR: glycine receptor; LGI1: leucine-rich, glioma inactivated 1; NMDAR: N-methyl-D-aspartate receptor; OCB: oligoclonal band. 
Author Contributions: Writing-original draft, Y.-C.K.; writing-review and editing, M.-IL., W.-C.W. and W.-T.L.; concept and design-W.-T.L.; funding acquisition, Y.-C.K. and W.-T.L. All authors have read and agreed to the published version of the manuscript.

Funding: This research was supported by the following research projects: 100-EDN03, 101-EDN01 and NCKUEDA10211.

Institutional Review Board Statement: Not applicable.

Informed Consent Statement: Not applicable.

Data Availability Statement: Data sharing not applicable.

Acknowledgments: The study was supported by grants from E-Da Hospital National Taiwan University Hospital Joint Research Program (100-EDN03, 101-EDN01) and National Cheng-Kung University E-Da Hospital Joint Program (NCKUEDA10211).

Conflicts of Interest: The authors declare no conflict of interest.

\begin{tabular}{|c|c|}
\hline \multicolumn{2}{|c|}{ Abbreviations } \\
\hline $\mathrm{AE}$ & autoimmune encephalitis \\
\hline AK5 & adenylate kinase 5 \\
\hline AMPAR & $\alpha$-amino-3-hydroxy-5-methyl-4-isoxazolepropionic acid receptor \\
\hline BBB & blood-brain barrier \\
\hline BG & basal ganglia \\
\hline CASPR2 & contactin-associated protein-like 2 \\
\hline CJD & Creutzfeldt-Jakob disease \\
\hline CNS & central nervous system \\
\hline CRMP5 & collapsin response-mediator protein- 5 \\
\hline CSF & cerebrospinal fluid \\
\hline DPPX/DPP6 & dipeptidyl peptidase-like protein 6 \\
\hline EEG & electroencephalography \\
\hline FDG-PET & fluorodeoxyglucose-positron emission tomography \\
\hline FLAIR & fluid-attenuated inversion recovery \\
\hline GABA-BR & $\gamma$-aminobutyric acid B receptor \\
\hline GAD & glutamic acid decarboxylase \\
\hline GlyR & glycine receptor \\
\hline HIV & human immunodeficiency virus \\
\hline HSV & herpes simplex virus \\
\hline HHV6 & human herpesvirus 6 \\
\hline ICI & immune checkpoint inhibitor \\
\hline IL & interleukin \\
\hline INF- $\gamma$ & interferon $-\gamma$ \\
\hline LE & limbic encephalitis \\
\hline LGI1 & leucine-rich, glioma inactivated 1 \\
\hline mGluR5 & metabotropic glutamate receptor subtype 5 \\
\hline MRI & magnetic resonance imaging \\
\hline NK & natural killer \\
\hline NMDAR & N-methyl-D-aspartate receptor \\
\hline OCB & oligoclonal band \\
\hline PNS & paraneoplastic syndrome \\
\hline SLE & systemic lupus erythematosus \\
\hline SOX1 & sex-determining region $\mathrm{Y}(\mathrm{SRY})$-box 1 \\
\hline SPS & stiff-person syndrome \\
\hline VZV & varicella zoster virus \\
\hline
\end{tabular}

\section{References}

1. Graus, F.; Titulaer, M.J.; Balu, R.; Benseler, S.; Bien, C.G.; Cellucci, T.; Cortese, I.; Dale, R.C.; Gelfand, J.M.; Geschwind, M.; et al. A clinical approach to diagnosis of autoimmune encephalitis. Lancet Neurol. 2016, 15, 391-404. [CrossRef]

2. Linnoila, J.J.; Binnicker, M.J.; Majed, M.; Klein, C.J.; McKeon, A. CSF herpes virus and autoantibody profiles in the evaluation of encephalitis. Neurol. Neuroimmunol. Neuroinflamm. 2016, 3, e245. [CrossRef] 
3. Graus, F.; Dalmau, J. Paraneoplastic neurological syndromes in the era of immune-checkpoint inhibitors. Nat. Rev. Clin. Oncol. 2019, 16, 535-548. [CrossRef] [PubMed]

4. Budhram, A.; Leung, A.; Nicolle, M.W.; Burneo, J.G. Diagnosing autoimmune limbic encephalitis. CMAJ 2019, 191, E529-E534. [CrossRef] [PubMed]

5. Pape, H.C.; Pare, D. Plastic synaptic networks of the amygdala for the acquisition, expression, and extinction of conditioned fear. Physiol. Rev. 2010, 90, 419-463. [CrossRef]

6. Aroniadou-Anderjaska, V.; Fritsch, B.; Qashu, F.; Braga, M.F. Pathology and pathophysiology of the amygdala in epileptogenesis and epilepsy. Epilepsy Res. 2008, 78, 102-116. [CrossRef]

7. Urbach, H.; Soeder, B.M.; Jeub, M.; Klockgether, T.; Meyer, B.; Bien, C.G. Serial MRI of limbic encephalitis. Neuroradiology 2006, 48, 380-386. [CrossRef]

8. Gadoth, A.; Pittock, S.J.; Dubey, D.; McKeon, A.; Britton, J.W.; Schmeling, J.E.; Smith, A.; Kotsenas, A.L.; Watson, R.E.; Lachance, D.H.; et al. Expanded phenotypes and outcomes among 256 LGI1/CASPR2-IgG-positive patients. Ann. Neurol. $2017,82,79-92$. [CrossRef]

9. Liu, X.; Shan, W.; Zhao, X.; Ren, J.; Ren, G.; Chen, C.; Shi, W.; Lv, R.; Li, Z.; Liu, Y.; et al. The Clinical Value of (18) F-FDG-PET in Autoimmune Encephalitis Associated With LGI1 Antibody. Front. Neurol. 2020, 11, 418. [CrossRef]

10. Boyko, M.; Au, K.L.K.; Casault, C.; de Robles, P.; Pfeffer, G. Systematic review of the clinical spectrum of CASPR2 antibody syndrome. J. Neurol. 2020, 267, 1137-1146. [CrossRef]

11. Graus, F.; Escudero, D.; Oleaga, L.; Bruna, J.; Villarejo-Galende, A.; Ballabriga, J.; Barcelo, M.I.; Gilo, F.; Popkirov, S.; Stourac, P.; et al. Syndrome and outcome of antibody-negative limbic encephalitis. Eur. J. Neurol. 2018, 25, 1011-1016. [CrossRef] [PubMed]

12. Giannoccaro, M.P.; Menassa, D.A.; Jacobson, L.; Coutinho, E.; Prota, G.; Lang, B.; Leite, M.I.; Cerundolo, V.; Liguori, R.; Vincent, A. Behaviour and neuropathology in mice injected with human contactin-associated protein 2 antibodies. Brain 2019, 142, $2000-2012$. [CrossRef] [PubMed]

13. Thompson, J.; Bi, M.; Murchison, A.G.; Makuch, M.; Bien, C.G.; Chu, K.; Farooque, P.; Gelfand, J.M.; Geschwind, M.D.; Hirsch, L.J.; et al. The importance of early immunotherapy in patients with faciobrachial dystonic seizures. Brain 2018, 141, 348-356. [CrossRef] [PubMed]

14. Joubert, B.; Saint-Martin, M.; Noraz, N.; Picard, G.; Rogemond, V.; Ducray, F.; Desestret, V.; Psimaras, D.; Delattre, J.Y.; Antoine, J.C.; et al. Characterization of a Subtype of Autoimmune Encephalitis with Anti-Contactin-Associated Protein-like 2 Antibodies in the Cerebrospinal Fluid, Prominent Limbic Symptoms, and Seizures. JAMA Neurol. 2016, 73, 1115-1124. [CrossRef]

15. Vidarsson, G.; Dekkers, G.; Rispens, T. IgG subclasses and allotypes: From structure to effector functions. Front. Immunol. 2014, 5, 520. [CrossRef]

16. Zuliani, L.; Nosadini, M.; Gastaldi, M.; Spatola, M.; Iorio, R.; Zoccarato, M.; Mariotto, S.; De Gaspari, P.; Perini, F.; Ferrari, S.; et al. Management of antibody-mediated autoimmune encephalitis in adults and children: Literature review and consensus-based practical recommendations. Neurol. Sci. 2019, 40, 2017-2030. [CrossRef]

17. Bien, C.G.; Vincent, A.; Barnett, M.H.; Becker, A.J.; Blumcke, I.; Graus, F.; Jellinger, K.A.; Reuss, D.E.; Ribalta, T.; Schlegel, J.; et al. Immunopathology of autoantibody-associated encephalitides: Clues for pathogenesis. Brain 2012, 135, 1622-1638. [CrossRef]

18. Bauer, J.; Bien, C.G. Neuropathology of autoimmune encephalitides. Handb. Clin. Neurol. 2016, 133, 107-120. [CrossRef]

19. van Sonderen, A.; Petit-Pedrol, M.; Dalmau, J.; Titulaer, M.J. The value of LGI1, Caspr2 and voltage-gated potassium channel antibodies in encephalitis. Nat. Rev. Neurol. 2017, 13, 290-301. [CrossRef]

20. Alexopoulos, H.; Dalakas, M.C. The immunobiology of autoimmune encephalitides. J. Autoimmun. 2019, 104, 102339. [CrossRef]

21. Lancaster, E.; Dalmau, J. Neuronal autoantigens-Pathogenesis, associated disorders and antibody testing. Nat. Rev. Neurol. 2012, 8, 380-390. [CrossRef] [PubMed]

22. van Coevorden-Hameete, M.H.; de Graaff, E.; Titulaer, M.J.; Hoogenraad, C.C.; Sillevis Smitt, P.A. Molecular and cellular mechanisms underlying anti-neuronal antibody mediated disorders of the central nervous system. Autoimmun. Rev. 2014, 13, 299-312. [CrossRef] [PubMed]

23. Irani, S.R.; Gelfand, J.M.; Al-Diwani, A.; Vincent, A. Cell-surface central nervous system autoantibodies: Clinical relevance and emerging paradigms. Ann. Neurol. 2014, 76, 168-184. [CrossRef] [PubMed]

24. Pittock, S.J.; Kryzer, T.J.; Lennon, V.A. Paraneoplastic antibodies coexist and predict cancer, not neurological syndrome. Ann. Neurol. 2004, 56, 715-719. [CrossRef] [PubMed]

25. Dalmau, J.; Geis, C.; Graus, F. Autoantibodies to Synaptic Receptors and Neuronal Cell Surface Proteins in Autoimmune Diseases of the Central Nervous System. Physiol. Rev. 2017, 97, 839-887. [CrossRef] [PubMed]

26. Ghimire, P.K.U.; Gajurel, B.P.; Karn, R.; Rajbhandari, R.; Paudel, S.; Gautam, N.; Ojha, R. Anti-LGI1, anti-GABABR, and Anti-CASPR2 encephalitides in Asia: A systematic review. Brain Behav. 2020, 10, e01793. [CrossRef]

27. Joubert, B.; Kerschen, P.; Zekeridou, A.; Desestret, V.; Rogemond, V.; Chaffois, M.O.; Ducray, F.; Larrue, V.; Daubail, B.; Idbaih, A.; et al. Clinical Spectrum of Encephalitis Associated with Antibodies Against the alpha-Amino-3-Hydroxy-5-Methyl-4Isoxazolepropionic Acid Receptor: Case Series and Review of the Literature. JAMA Neurol. 2015, 72, 1163-1169. [CrossRef]

28. Fukuda, T.G.; do Rosario, M.S.; Branco, R.C.C.; Fukuda, J.S.; de Souza, E.S.R.A.; Oliveira-Filho, J.; de Jesus, P.A.P. Multiple paraneoplastic antibodies (anti-SOX1, anti-Hu, and anti-Amphiphysin) detected in a patient with limbic encephalitis and small cell lung cancer. Neurol. India 2017, 65, 1127-1128. [CrossRef] 
29. Jia, Y.; Wang, J.; Xue, L.; Hou, Y. Limbic encephalitis associated with AMPA receptor and CRMP5 antibodies: A case report and literature review. Brain Behav. 2020, 10, e01528. [CrossRef]

30. Yoneda, M. Hashimoto's Encephalopathy and Autoantibodies. Brain Nerve 2018, 70, 305-314. [CrossRef]

31. Pilli, D.; Zou, A.; Tea, F.; Dale, R.C.; Brilot, F. Expanding Role of T Cells in Human Autoimmune Diseases of the Central Nervous System. Front. Immunol. 2017, 8, 652. [CrossRef] [PubMed]

32. Melzer, N.; Meuth, S.G.; Wiendl, H. CD8+ T cells and neuronal damage: Direct and collateral mechanisms of cytotoxicity and impaired electrical excitability. FASEB J. 2009, 23, 3659-3673. [CrossRef] [PubMed]

33. Ehling, P.; Melzer, N.; Budde, T.; Meuth, S.G. CD8(+) T Cell-Mediated Neuronal Dysfunction and Degeneration in Limbic Encephalitis. Front. Neurol. 2015, 6, 163. [CrossRef] [PubMed]

34. Waterhouse, N.J.; Sutton, V.R.; Sedelies, K.A.; Ciccone, A.; Jenkins, M.; Turner, S.J.; Bird, P.I.; Trapani, J.A. Cytotoxic T lymphocyteinduced killing in the absence of granzymes $\mathrm{A}$ and $\mathrm{B}$ is unique and distinct from both apoptosis and perforin-dependent lysis. J. Cell Biol. 2006, 173, 133-144. [CrossRef]

35. Kreutzfeldt, M.; Bergthaler, A.; Fernandez, M.; Bruck, W.; Steinbach, K.; Vorm, M.; Coras, R.; Blumcke, I.; Bonilla, W.V.; Fleige, A.; et al. Neuroprotective intervention by interferon-gamma blockade prevents CD8+ T cell-mediated dendrite and synapse loss. $J$. Exp. Med. 2013, 210, 2087-2103. [CrossRef]

36. Chung, W.S.; Welsh, C.A.; Barres, B.A.; Stevens, B. Do glia drive synaptic and cognitive impairment in disease? Nat. Neurosci. 2015, 18, 1539-1545. [CrossRef]

37. Wesselingh, R.; Butzkueven, H.; Buzzard, K.; Tarlinton, D.; O’Brien, T.J.; Monif, M. Innate Immunity in the Central Nervous System: A Missing Piece of the Autoimmune Encephalitis Puzzle? Front. Immunol. 2019, 10, 2066. [CrossRef]

38. Khan, N.L.; Jeffree, M.A.; Good, C.; Macleod, W.; Al-Sarraj, S. Histopathology of VGKC antibody-associated limbic encephalitis. Neurology 2009, 72, 1703-1705. [CrossRef]

39. Amhaoul, H.; Hamaide, J.; Bertoglio, D.; Reichel, S.N.; Verhaeghe, J.; Geerts, E.; Van Dam, D.; De Deyn, P.P.; Kumar-Singh, S.; Katsifis, A.; et al. Brain inflammation in a chronic epilepsy model: Evolving pattern of the translocator protein during epileptogenesis. Neurobiol. Dis. 2015, 82, 526-539. [CrossRef]

40. Yang, M.T.; Lin, Y.C.; Ho, W.H.; Liu, C.L.; Lee, W.T. Everolimus is better than rapamycin in attenuating neuroinflammation in kainic acid-induced seizures. J. Neuroinflamm. 2017, 14, 15. [CrossRef]

41. Tomczak, A.; Su, E.; Tugizova, M.; Carlson, A.M.; Kipp, L.B.; Feng, H.; Han, M.H. A case of GFAP-astroglial autoimmunity presenting with reversible parkinsonism. Mult. Scler. Relat. Disord. 2019, 39, 101900. [CrossRef] [PubMed]

42. Ismail, F.S.; Faustmann, P.M. Astrocytes and their potential role in anti-NMDA receptor encephalitis. Med. Hypotheses 2020, 139, 109612. [CrossRef] [PubMed]

43. Habbas, S.; Santello, M.; Becker, D.; Stubbe, H.; Zappia, G.; Liaudet, N.; Klaus, F.R.; Kollias, G.; Fontana, A.; Pryce, C.R.; et al. Neuroinflammatory TNFalpha Impairs Memory via Astrocyte Signaling. Cell 2015, 163, 1730-1741. [CrossRef] [PubMed]

44. Hebert, J.; Gros, P.; Lapointe, S.; Amtashar, F.S.; Steriade, C.; Maurice, C.; Wennberg, R.A.; Day, G.S.; Tang-Wai, D.F. Searching for autoimmune encephalitis: Beware of normal CSF. J. Neuroimmunol. 2020, 345, 577285. [CrossRef]

45. Hansen, N.; Schwing, K.; Onder, D.; Widman, G.; Leelaarporn, P.; Prusseit, I.; Surges, R.; Melzer, N.; Gross, C.; Becker, A.J.; et al. Low CSF CD4/CD8+ T-cell proportions are associated with blood-CSF barrier dysfunction in limbic encephalitis. Epilepsy Behav. 2020, 102, 106682. [CrossRef]

46. Lin, Y.T.; Yang, X.; Lv, J.W.; Liu, X.W.; Wang, S.J. CXCL13 Is A Biomarker of Anti-Leucine-Rich Glioma-Inactivated Protein 1 Encephalitis Patients. Neuropsychiatr. Dis. Treat. 2019, 15, 2909-2915. [CrossRef]

47. Roberts, W.K.; Blachere, N.E.; Frank, M.O.; Dousmanis, A.; Ransohoff, R.M.; Darnell, R.B. A destructive feedback loop mediated by CXCL10 in central nervous system inflammatory disease. Ann. Neurol. 2015, 78, 619-629. [CrossRef]

48. Kortvelyessy, P.; Goihl, A.; Guttek, K.; Schraven, B.; Pruss, H.; Reinhold, D. Serum and CSF cytokine levels mirror different neuroimmunological mechanisms in patients with LGI1 and Caspr2 encephalitis. Cytokine 2020, 135, 155226. [CrossRef]

49. Michael, B.D.; Griffiths, M.J.; Granerod, J.; Brown, D.; Davies, N.W.; Borrow, R.; Solomon, T. Characteristic Cytokine and Chemokine Profiles in Encephalitis of Infectious, Immune-Mediated, and Unknown Aetiology. PLoS ONE 2016, 11, e0146288. [CrossRef]

50. Jiang, J.X.; Fewings, N.; Dervish, S.; Fois, A.F.; Duma, S.R.; Silsby, M.; Bandodkar, S.; Ramanathan, S.; Bleasel, A.; John, B.; et al. Novel Surrogate Markers of CNS Inflammation in CSF in the Diagnosis of Autoimmune Encephalitis. Front. Neurol. 2019, 10, 1390. [CrossRef]

51. Spolski, R.; Leonard, W.J. Interleukin-21: A double-edged sword with therapeutic potential. Nat. Rev. Drug Discov. 2014, 13, 379-395. [CrossRef] [PubMed]

52. Liu, M.; Guo, S.; Hibbert, J.M.; Jain, V.; Singh, N.; Wilson, N.O.; Stiles, J.K. CXCL10/IP-10 in infectious diseases pathogenesis and potential therapeutic implications. Cytokine Growth Factor Rev. 2011, 22, 121-130. [CrossRef] [PubMed]

53. Kim, T.J.; Lee, S.T.; Moon, J.; Sunwoo, J.S.; Byun, J.I.; Lim, J.A.; Shin, Y.W.; Jun, J.S.; Lee, H.S.; Lee, W.J.; et al. Anti-LGI1 encephalitis is associated with unique HLA subtypes. Ann. Neurol. 2017, 81, 183-192. [CrossRef] [PubMed]

54. Binks, S.; Varley, J.; Lee, W.; Makuch, M.; Elliott, K.; Gelfand, J.M.; Jacob, S.; Leite, M.I.; Maddison, P.; Chen, M.; et al. Distinct HLA associations of LGI1 and CASPR2-antibody diseases. Brain 2018, 141, 2263-2271. [CrossRef] [PubMed] 
55. Muniz-Castrillo, S.; Ambati, A.; Dubois, V.; Vogrig, A.; Joubert, B.; Rogemond, V.; Picard, G.; Lin, L.; Fabien, N.; Mignot, E.; et al. Primary DQ effect in the association between HLA and neurological syndromes with anti-GAD65 antibodies. J. Neurol. 2020, 267, 1906-1911. [CrossRef] [PubMed]

56. Shojima, Y.; Nishioka, K.; Watanabe, M.; Jo, T.; Tanaka, K.; Takashima, H.; Noda, K.; Okuma, Y.; Urabe, T.; Yokoyama, K.; et al. Clinical Characterization of Definite Autoimmune Limbic Encephalitis: A 30-case Series. Intern. Med. 2019, 58, 3369-3378. [CrossRef]

57. Dalmau, J.; Lancaster, E.; Martinez-Hernandez, E.; Rosenfeld, M.R.; Balice-Gordon, R. Clinical experience and laboratory investigations in patients with anti-NMDAR encephalitis. Lancet Neurol. 2011, 10, 63-74. [CrossRef]

58. Small, M.; Treilleux, I.; Couillault, C.; Pissaloux, D.; Picard, G.; Paindavoine, S.; Attignon, V.; Wang, Q.; Rogemond, V.; Lay, S.; et al. Genetic alterations and tumor immune attack in Yo paraneoplastic cerebellar degeneration. Acta Neuropathol. 2018, 135, 569-579. [CrossRef]

59. Melzer, N.; Meuth, S.G.; Wiendl, H. Paraneoplastic and non-paraneoplastic autoimmunity to neurons in the central nervous system. J. Neurol. 2013, 260, 1215-1233. [CrossRef]

60. Vogrig, A.; Gigli, G.L.; Segatti, S.; Corazza, E.; Marini, A.; Bernardini, A.; Valent, F.; Fabris, M.; Curcio, F.; Brigo, F.; et al. Epidemiology of paraneoplastic neurological syndromes: A population-based study. J. Neurol. 2020, 267, 26-35. [CrossRef]

61. Gultekin, S.H.; Rosenfeld, M.R.; Voltz, R.; Eichen, J.; Posner, J.B.; Dalmau, J. Paraneoplastic limbic encephalitis: Neurological symptoms, immunological findings and tumour association in 50 patients. Brain 2000, 123 Pt 7, 1481-1494. [CrossRef]

62. Erkmen, C.P.; Fadul, C.E.; Dalmau, J.; Erkmen, K. Thymoma-associated paraneoplastic encephalitis (TAPE): Diagnosis and treatment of a potentially fatal condition. J. Thorac. Cardiovasc. Surg. 2011, 141, e17-e20. [CrossRef] [PubMed]

63. van Coevorden-Hameete, M.H.; de Bruijn, M.; de Graaff, E.; Bastiaansen, D.; Schreurs, M.W.J.; Demmers, J.A.A.; Ramberger, M.; Hulsenboom, E.S.P.; Nagtzaam, M.M.P.; Boukhrissi, S.; et al. The expanded clinical spectrum of anti-GABABR encephalitis and added value of KCTD16 autoantibodies. Brain 2019, 142, 1631-1643. [CrossRef] [PubMed]

64. Irani, S.R.; Alexander, S.; Waters, P.; Kleopa, K.A.; Pettingill, P.; Zuliani, L.; Peles, E.; Buckley, C.; Lang, B.; Vincent, A. Antibodies to Kv1 potassium channel-complex proteins leucine-rich, glioma inactivated 1 protein and contactin-associated protein-2 in limbic encephalitis, Morvan's syndrome and acquired neuromyotonia. Brain 2010, 133, 2734-2748. [CrossRef] [PubMed]

65. Irani, S.R.; Pettingill, P.; Kleopa, K.A.; Schiza, N.; Waters, P.; Mazia, C.; Zuliani, L.; Watanabe, O.; Lang, B.; Buckley, C.; et al. Morvan syndrome: Clinical and serological observations in 29 cases. Ann. Neurol. 2012, 72, 241-255. [CrossRef]

66. Dalmau, J.; Rosenfeld, M.R. Paraneoplastic syndromes of the CNS. Lancet Neurol. 2008, 7, 327-340. [CrossRef]

67. Armangue, T.; Spatola, M.; Vlagea, A.; Mattozzi, S.; Carceles-Cordon, M.; Martinez-Heras, E.; Llufriu, S.; Muchart, J.; Erro, M.E.; Abraira, L.; et al. Frequency, symptoms, risk factors, and outcomes of autoimmune encephalitis after herpes simplex encephalitis: A prospective observational study and retrospective analysis. Lancet Neurol. 2018, 17, 760-772. [CrossRef]

68. Mohammad, S.S.; Sinclair, K.; Pillai, S.; Merheb, V.; Aumann, T.D.; Gill, D.; Dale, R.C.; Brilot, F. Herpes simplex encephalitis relapse with chorea is associated with autoantibodies to N-Methyl-D-aspartate receptor or dopamine-2 receptor. Mov. Disord. 2014, 29, 117-122. [CrossRef]

69. Peters, J.; Wesley, S.F. Case of concurrent herpes simplex and autoimmune encephalitis. Neurol. Neuroimmunol. Neuroinflamm. 2020, 7. [CrossRef]

70. Hoftberger, R.; Armangue, T.; Leypoldt, F.; Graus, F.; Dalmau, J. Clinical Neuropathology practice guide 4-2013: Post-herpes simplex encephalitis: N-methyl-Daspartate receptor antibodies are part of the problem. Clin. Neuropathol. 2013, 32, 251-254. [CrossRef]

71. Seeley, W.W.; Marty, F.M.; Holmes, T.M.; Upchurch, K.; Soiffer, R.J.; Antin, J.H.; Baden, L.R.; Bromfield, E.B. Post-transplant acute limbic encephalitis: Clinical features and relationship to HHV6. Neurology 2007, 69, 156-165. [CrossRef] [PubMed]

72. Dubey, D.; David, W.S.; Amato, A.A.; Reynolds, K.L.; Clement, N.F.; Chute, D.F.; Cohen, J.V.; Lawrence, D.P.; Mooradian, M.J.; Sullivan, R.J.; et al. Varied phenotypes and management of immune checkpoint inhibitor-associated neuropathies. Neurology 2019, 93, e1093-e1103. [CrossRef] [PubMed]

73. Vogrig, A.; Muniz-Castrillo, S.; Joubert, B.; Picard, G.; Rogemond, V.; Marchal, C.; Chiappa, A.M.; Chanson, E.; Skowron, F.; Leblanc, A.; et al. Central nervous system complications associated with immune checkpoint inhibitors. J. Neurol. Neurosurg. Psychiatry 2020, 91, 772-778. [CrossRef] [PubMed]

74. Ribas, A.; Wolchok, J.D. Cancer immunotherapy using checkpoint blockade. Science 2018, 359, 1350-1355. [CrossRef] [PubMed]

75. Papadopoulos, K.P.; Romero, R.S.; Gonzalez, G.; Dix, J.E.; Lowy, I.; Fury, M. Anti-Hu-Associated Autoimmune Limbic Encephalitis in a Patient with PD-1 Inhibitor-Responsive Myxoid Chondrosarcoma. Oncologist 2018, 23, 118-120. [CrossRef] [PubMed]

76. Chung, M.; Jaffer, M.; Verma, N.; Mokhtari, S.; Ramsakal, A.; Peguero, E. Immune checkpoint inhibitor induced anti-glutamic acid decarboxylase 65 (Anti-GAD 65) limbic encephalitis responsive to intravenous immunoglobulin and plasma exchange. J. Neurol. 2020, 267, 1023-1025. [CrossRef]

77. Vogrig, A.; Fouret, M.; Joubert, B.; Picard, G.; Rogemond, V.; Pinto, A.L.; Muniz-Castrillo, S.; Roger, M.; Raimbourg, J.; Dayen, C.; et al. Increased frequency of anti-Ma2 encephalitis associated with immune checkpoint inhibitors. Neurol. Neuroimmunol. Neuroinflamm. 2019, 6. [CrossRef]

78. Brown, M.P.; Hissaria, P.; Hsieh, A.H.; Kneebone, C.; Vallat, W. Autoimmune limbic encephalitis with anti-contactin-associated protein-like 2 antibody secondary to pembrolizumab therapy. J. Neuroimmunol. 2017, 305, 16-18. [CrossRef] 
79. Hacohen, Y.; Singh, R.; Rossi, M.; Lang, B.; Hemingway, C.; Lim, M.; Vincent, A. Clinical relevance of voltage-gated potassium channel-complex antibodies in children. Neurology 2015, 85, 967-975. [CrossRef]

80. Lang, B.; Makuch, M.; Moloney, T.; Dettmann, I.; Mindorf, S.; Probst, C.; Stoecker, W.; Buckley, C.; Newton, C.R.; Leite, M.I.; et al. Intracellular and non-neuronal targets of voltage-gated potassium channel complex antibodies. J. Neurol. Neurosurg. Psychiatry 2017, 88, 353-361. [CrossRef]

81. Lilleker, J.B.; Jones, M.S.; Mohanraj, R. VGKC complex antibodies in epilepsy: Diagnostic yield and therapeutic implications. Seizure 2013, 22, 776-779. [CrossRef] [PubMed]

82. van Sonderen, A.; Schreurs, M.W.; Wirtz, P.W.; Sillevis Smitt, P.A.; Titulaer, M.J. From VGKC to LGI1 and Caspr2 encephalitis: The evolution of a disease entity over time. Autoimmun. Rev. 2016, 15, 970-974. [CrossRef] [PubMed]

83. van Sonderen, A.; Schreurs, M.W.; de Bruijn, M.A.; Boukhrissi, S.; Nagtzaam, M.M.; Hulsenboom, E.S.; Enting, R.H.; Thijs, R.D.; Wirtz, P.W.; Sillevis Smitt, P.A.; et al. The relevance of VGKC positivity in the absence of LGI1 and Caspr2 antibodies. Neurology 2016, 86, 1692-1699. [CrossRef] [PubMed]

84. Klein, C.J.; Lennon, V.A.; Aston, P.A.; McKeon, A.; O’Toole, O.; Quek, A.; Pittock, S.J. Insights from LGI1 and CASPR2 potassium channel complex autoantibody subtyping. JAMA Neurol. 2013, 70, 229-234. [CrossRef] [PubMed]

85. Michael, S.; Waters, P.; Irani, S.R. Stop testing for autoantibodies to the VGKC-complex: Only request LGI1 and CASPR2. Pr. Neurol. 2020, 20, 377-384. [CrossRef] [PubMed]

86. Fukata, Y.; Yokoi, N.; Miyazaki, Y.; Fukata, M. The LGI1-ADAM22 protein complex in synaptic transmission and synaptic disorders. Neurosci. Res. 2017, 116, 39-45. [CrossRef] [PubMed]

87. Ohkawa, T.; Satake, S.; Yokoi, N.; Miyazaki, Y.; Ohshita, T.; Sobue, G.; Takashima, H.; Watanabe, O.; Fukata, Y.; Fukata, M. Identification and characterization of GABA(A) receptor autoantibodies in autoimmune encephalitis. J. Neurosci. 2014, 34, 8151-8163. [CrossRef]

88. Boillot, M.; Huneau, C.; Marsan, E.; Lehongre, K.; Navarro, V.; Ishida, S.; Dufresnois, B.; Ozkaynak, E.; Garrigue, J.; Miles, R.; et al. Glutamatergic neuron-targeted loss of LGI1 epilepsy gene results in seizures. Brain 2014, 137, 2984-2996. [CrossRef]

89. Ohkawa, T.; Fukata, Y.; Yamasaki, M.; Miyazaki, T.; Yokoi, N.; Takashima, H.; Watanabe, M.; Watanabe, O.; Fukata, M. Autoantibodies to epilepsy-related LGI1 in limbic encephalitis neutralize LGI1-ADAM22 interaction and reduce synaptic AMPA receptors. J. Neurosci. 2013, 33, 18161-18174. [CrossRef]

90. Petit-Pedrol, M.; Sell, J.; Planaguma, J.; Mannara, F.; Radosevic, M.; Haselmann, H.; Ceanga, M.; Sabater, L.; Spatola, M.; Soto, D.; et al. LGI1 antibodies alter Kv1.1 and AMPA receptors changing synaptic excitability, plasticity and memory. Brain 2018, 141, 3144-3159. [CrossRef]

91. Irani, S.R.; Michell, A.W.; Lang, B.; Pettingill, P.; Waters, P.; Johnson, M.R.; Schott, J.M.; Armstrong, R.J.; Zagami, A.S.; Bleasel, A.; et al. Faciobrachial dystonic seizures precede Lgi1 antibody limbic encephalitis. Ann. Neurol. 2011, 69, 892-900. [CrossRef] [PubMed]

92. Malter, M.P.; Frisch, C.; Schoene-Bake, J.C.; Helmstaedter, C.; Wandinger, K.P.; Stoecker, W.; Urbach, H.; Surges, R.; Elger, C.E.; Vincent, A.V.; et al. Outcome of limbic encephalitis with VGKC-complex antibodies: Relation to antigenic specificity. J. Neurol. 2014, 261, 1695-1705. [CrossRef] [PubMed]

93. Bastiaansen, A.E.M.; van Sonderen, A.; Titulaer, M.J. Autoimmune encephalitis with anti-leucine-rich glioma-inactivated 1 or anti-contactin-associated protein-like 2 antibodies (formerly called voltage-gated potassium channel-complex antibodies). Curr. Opin. Neurol. 2017, 30, 302-309. [CrossRef] [PubMed]

94. Saint-Martin, M.; Joubert, B.; Pellier-Monnin, V.; Pascual, O.; Noraz, N.; Honnorat, J. Contactin-associated protein-like 2, a protein of the neurexin family involved in several human diseases. Eur. J. Neurosci. 2018, 48, 1906-1923. [CrossRef]

95. Ogawa, Y.; Oses-Prieto, J.; Kim, M.Y.; Horresh, I.; Peles, E.; Burlingame, A.L.; Trimmer, J.S.; Meijer, D.; Rasband, M.N. ADAM22, a Kv1 channel-interacting protein, recruits membrane-associated guanylate kinases to juxtaparanodes of myelinated axons. J. Neurosci. 2010, 30, 1038-1048. [CrossRef]

96. Patterson, K.R.; Dalmau, J.; Lancaster, E. Mechanisms of Caspr2 antibodies in autoimmune encephalitis and neuromyotonia. Ann. Neurol. 2018, 83, 40-51. [CrossRef]

97. Dawes, J.M.; Weir, G.A.; Middleton, S.J.; Patel, R.; Chisholm, K.I.; Pettingill, P.; Peck, L.J.; Sheridan, J.; Shakir, A.; Jacobson, L.; et al. Immune or Genetic-Mediated Disruption of CASPR2 Causes Pain Hypersensitivity Due to Enhanced Primary Afferent Excitability. Neuron 2018, 97, 806-822.e10. [CrossRef]

98. Klein, C.J.; Lennon, V.A.; Aston, P.A.; McKeon, A.; Pittock, S.J. Chronic pain as a manifestation of potassium channel-complex autoimmunity. Neurology 2012, 79, 1136-1144. [CrossRef]

99. Traynelis, S.F.; Wollmuth, L.P.; McBain, C.J.; Menniti, F.S.; Vance, K.M.; Ogden, K.K.; Hansen, K.B.; Yuan, H.; Myers, S.J.; Dingledine, R. Glutamate receptor ion channels: Structure, regulation, and function. Pharmacol. Rev. 2010, 62, 405-496. [CrossRef]

100. Sprengel, R. Role of AMPA receptors in synaptic plasticity. Cell Tissue Res. 2006, 326, 447-455. [CrossRef]

101. Lai, M.; Hughes, E.G.; Peng, X.; Zhou, L.; Gleichman, A.J.; Shu, H.; Mata, S.; Kremens, D.; Vitaliani, R.; Geschwind, M.D.; et al. AMPA receptor antibodies in limbic encephalitis alter synaptic receptor location. Ann. Neurol. 2009, 65, 424-434. [CrossRef] [PubMed]

102. Peng, X.; Hughes, E.G.; Moscato, E.H.; Parsons, T.D.; Dalmau, J.; Balice-Gordon, R.J. Cellular plasticity induced by anti-alphaamino-3-hydroxy-5-methyl-4-isoxazolepropionic acid (AMPA) receptor encephalitis antibodies. Ann. Neurol. 2015, 77, 381-398. [CrossRef] [PubMed] 
103. Laurido-Soto, O.; Brier, M.R.; Simon, L.E.; McCullough, A.; Bucelli, R.C.; Day, G.S. Patient characteristics and outcome associations in AMPA receptor encephalitis. J. Neurol. 2019, 266, 450-460. [CrossRef] [PubMed]

104. Nicoletti, F.; Bockaert, J.; Collingridge, G.L.; Conn, P.J.; Ferraguti, F.; Schoepp, D.D.; Wroblewski, J.T.; Pin, J.P. Metabotropic glutamate receptors: From the workbench to the bedside. Neuropharmacology 2011, 60, 1017-1041. [CrossRef] [PubMed]

105. Spatola, M.; Sabater, L.; Planaguma, J.; Martinez-Hernandez, E.; Armangue, T.; Pruss, H.; Iizuka, T.; Caparo Oblitas, R.L.; Antoine, J.C.; Li, R.; et al. Encephalitis with mGluR5 antibodies: Symptoms and antibody effects. Neurology 2018, 90, e1964-e1972. [CrossRef] [PubMed]

106. Lancaster, E.; Martinez-Hernandez, E.; Titulaer, M.J.; Boulos, M.; Weaver, S.; Antoine, J.C.; Liebers, E.; Kornblum, C.; Bien, C.G.; Honnorat, J.; et al. Antibodies to metabotropic glutamate receptor 5 in the Ophelia syndrome. Neurology 2011, 77, 1698-1701. [CrossRef]

107. Boronat, A.; Gelfand, J.M.; Gresa-Arribas, N.; Jeong, H.Y.; Walsh, M.; Roberts, K.; Martinez-Hernandez, E.; Rosenfeld, M.R.; Balice-Gordon, R.; Graus, F.; et al. Encephalitis and antibodies to dipeptidyl-peptidase-like protein-6, a subunit of Kv4.2 potassium channels. Ann. Neurol. 2013, 73, 120-128. [CrossRef]

108. Nadal, M.S.; Ozaita, A.; Amarillo, Y.; Vega-Saenz de Miera, E.; Ma, Y.; Mo, W.; Goldberg, E.M.; Misumi, Y.; Ikehara, Y.; Neubert, T.A.; et al. The CD26-related dipeptidyl aminopeptidase-like protein DPPX is a critical component of neuronal A-type K+ channels. Neuron 2003, 37, 449-461. [CrossRef]

109. Clark, B.D.; Kwon, E.; Maffie, J.; Jeong, H.Y.; Nadal, M.; Strop, P.; Rudy, B. DPP6 Localization in Brain Supports Function as a Kv4 Channel Associated Protein. Front. Mol. Neurosci. 2008, 1, 8. [CrossRef]

110. Tobin, W.O.; Lennon, V.A.; Komorowski, L.; Probst, C.; Clardy, S.L.; Aksamit, A.J.; Appendino, J.P.; Lucchinetti, C.F.; Matsumoto, J.Y.; Pittock, S.J.; et al. DPPX potassium channel antibody: Frequency, clinical accompaniments, and outcomes in 20 patients. Neurology 2014, 83, 1797-1803. [CrossRef]

111. Hara, M.; Arino, H.; Petit-Pedrol, M.; Sabater, L.; Titulaer, M.J.; Martinez-Hernandez, E.; Schreurs, M.W.; Rosenfeld, M.R.; Graus, F.; Dalmau, J. DPPX antibody-associated encephalitis: Main syndrome and antibody effects. Neurology 2017, 88, 1340-1348. [CrossRef] [PubMed]

112. Linnoila, J.J.; Rosenfeld, M.R.; Dalmau, J. Neuronal surface antibody-mediated autoimmune encephalitis. Semin. Neurol. 2014, 34, 458-466. [CrossRef] [PubMed]

113. Emson, P.C. GABA(B) receptors: Structure and function. Prog. Brain Res. 2007, 160, 43-57. [CrossRef]

114. Bettler, B.; Kaupmann, K.; Mosbacher, J.; Gassmann, M. Molecular structure and physiological functions of GABA(B) receptors. Physiol. Rev. 2004, 84, 835-867. [CrossRef] [PubMed]

115. Lancaster, E.; Lai, M.; Peng, X.; Hughes, E.; Constantinescu, R.; Raizer, J.; Friedman, D.; Skeen, M.B.; Grisold, W.; Kimura, A.; et al. Antibodies to the GABA(B) receptor in limbic encephalitis with seizures: Case series and characterisation of the antigen. Lancet Neurol. 2010, 9, 67-76. [CrossRef]

116. Hoftberger, R.; Titulaer, M.J.; Sabater, L.; Dome, B.; Rozsas, A.; Hegedus, B.; Hoda, M.A.; Laszlo, V.; Ankersmit, H.J.; Harms, L.; et al. Encephalitis and GABAB receptor antibodies: Novel findings in a new case series of 20 patients. Neurology 2013, 81, 1500-1506. [CrossRef]

117. Jeffery, O.J.; Lennon, V.A.; Pittock, S.J.; Gregory, J.K.; Britton, J.W.; McKeon, A. GABAB receptor autoantibody frequency in service serologic evaluation. Neurology 2013, 81, 882-887. [CrossRef]

118. Dogan Onugoren, M.; Deuretzbacher, D.; Haensch, C.A.; Hagedorn, H.J.; Halve, S.; Isenmann, S.; Kramme, C.; Lohner, H.; Melzer, N.; Monotti, R.; et al. Limbic encephalitis due to GABAB and AMPA receptor antibodies: A case series. J. Neurol. Neurosurg. Psychiatry 2015, 86, 965-972. [CrossRef]

119. Arino, H.; Hoftberger, R.; Gresa-Arribas, N.; Martinez-Hernandez, E.; Armangue, T.; Kruer, M.C.; Arpa, J.; Domingo, J.; Rojc, B.; Bataller, L.; et al. Paraneoplastic Neurological Syndromes and Glutamic Acid Decarboxylase Antibodies. JAMA Neurol. 2015, 72, 874-881. [CrossRef]

120. Zhang, X.; Lang, Y.; Sun, L.; Zhang, W.; Lin, W.; Cui, L. Clinical characteristics and prognostic analysis of anti-gammaaminobutyric acid-B (GABA-B) receptor encephalitis in Northeast China. BMC Neurol. 2020, 20, 1. [CrossRef]

121. Blinder, T.; Lewerenz, J. Cerebrospinal Fluid Findings in Patients With Autoimmune Encephalitis-A Systematic Analysis. Front. Neurol. 2019, 10, 804. [CrossRef] [PubMed]

122. Moser, A.; Hanssen, H.; Wandinger, K.P. Excessively increased CSF glutamate levels in GABAB-receptor antibody associated encephalitis: A case report. J. Neurol. Sci. 2018, 388, 10-11. [CrossRef] [PubMed]

123. Golombeck, K.S.; Bonte, K.; Monig, C.; van Loo, K.M.; Hartwig, M.; Schwindt, W.; Widman, G.; Lindenau, M.; Becker, A.J.; Glatzel, M.; et al. Evidence of a pathogenic role for CD8(+) T cells in anti-GABAB receptor limbic encephalitis. Neurol. Neuroimmunol. Neuroinflamm. 2016, 3, e232. [CrossRef] [PubMed]

124. Cui, J.; Bu, H.; He, J.; Zhao, Z.; Han, W.; Gao, R.; Li, X.; Li, Q.; Guo, X.; Zou, Y. The gamma-aminobutyric acid-B receptor (GABAB) encephalitis: Clinical manifestations and response to immunotherapy. Int. J. Neurosci. 2018, 128, 627-633. [CrossRef]

125. Solimena, M.; Folli, F.; Aparisi, R.; Pozza, G.; De Camilli, P. Autoantibodies to GABA-ergic neurons and pancreatic beta cells in stiff-man syndrome. N. Engl. J. Med. 1990, 322, 1555-1560. [CrossRef] [PubMed]

126. Ali, F.; Rowley, M.; Jayakrishnan, B.; Teuber, S.; Gershwin, M.E.; Mackay, I.R. Stiff-person syndrome (SPS) and anti-GAD-related CNS degenerations: Protean additions to the autoimmune central neuropathies. J. Autoimmun. 2011, 37, 79-87. [CrossRef] [PubMed] 
127. Fenalti, G.; Buckle, A.M. Structural biology of the GAD autoantigen. Autoimmun. Rev. 2010, 9, 148-152. [CrossRef]

128. Dalakas, M.C. Progress and stiff challenges in understanding the role of GAD-antibodies in stiff-person syndrome. Exp. Neurol. 2013, 247, 303-307. [CrossRef]

129. Walikonis, J.E.; Lennon, V.A. Radioimmunoassay for glutamic acid decarboxylase (GAD65) autoantibodies as a diagnostic aid for stiff-man syndrome and a correlate of susceptibility to type 1 diabetes mellitus. Mayo Clin. Proc. 1998, 73, 1161-1166. [CrossRef]

130. Munoz-Lopetegi, A.; de Bruijn, M.; Boukhrissi, S.; Bastiaansen, A.E.M.; Nagtzaam, M.M.P.; Hulsenboom, E.S.P.; Boon, A.J.W.; Neuteboom, R.F.; de Vries, J.M.; Sillevis Smitt, P.A.E.; et al. Neurologic syndromes related to anti-GAD65: Clinical and serologic response to treatment. Neurol. Neuroimmunol. Neuroinflamm. 2020, 7. [CrossRef]

131. Raju, R.; Foote, J.; Banga, J.P.; Hall, T.R.; Padoa, C.J.; Dalakas, M.C.; Ortqvist, E.; Hampe, C.S. Analysis of GAD65 autoantibodies in Stiff-Person syndrome patients. J. Immunol. 2005, 175, 7755-7762. [CrossRef]

132. Vianello, M.; Giometto, B.; Vassanelli, S.; Canato, M.; Betterle, C.; Mucignat, C. Peculiar labeling of cultured hippocampal neurons by different sera harboring anti-glutamic acid decarboxylase autoantibodies (GAD-Ab). Exp. Neurol. 2006, 202, 514-518. [CrossRef] [PubMed]

133. Burton, A.R.; Baquet, Z.; Eisenbarth, G.S.; Tisch, R.; Smeyne, R.; Workman, C.J.; Vignali, D.A. Central nervous system destruction mediated by glutamic acid decarboxylase-specific CD4+ T cells. J. Immunol. 2010, 184, 4863-4870. [CrossRef] [PubMed]

134. Cheramy, M.; Hampe, C.S.; Ludvigsson, J.; Casas, R. Characteristics of in-vitro phenotypes of glutamic acid decarboxylase 65 autoantibodies in high-titre individuals. Clin. Exp. Immunol. 2013, 171, 247-254. [CrossRef]

135. Malter, M.P.; Helmstaedter, C.; Urbach, H.; Vincent, A.; Bien, C.G. Antibodies to glutamic acid decarboxylase define a form of limbic encephalitis. Ann. Neurol. 2010, 67, 470-478. [CrossRef] [PubMed]

136. Chang, T.; Alexopoulos, H.; Pettingill, P.; McMenamin, M.; Deacon, R.; Erdelyi, F.; Szabo, G.; Buckley, C.J.; Vincent, A. Immunization against GAD induces antibody binding to GAD-independent antigens and brainstem GABAergic neuronal loss. PLoS ONE 2013, 8, e72921. [CrossRef]

137. Haberlandt, E.; Bast, T.; Ebner, A.; Holthausen, H.; Kluger, G.; Kravljanac, R.; Kroll-Seger, J.; Kurlemann, G.; Makowski, C.; Rostasy, K.; et al. Limbic encephalitis in children and adolescents. Arch. Dis. Child. 2011, 96, 186-191. [CrossRef]

138. Baizabal-Carvallo, J.F. The neurological syndromes associated with glutamic acid decarboxylase antibodies. J. Autoimmun. 2019, 101, 35-47. [CrossRef]

139. Gagnon, M.M.; Savard, M. Limbic Encephalitis Associated With GAD65 Antibodies: Brief Review of the Relevant literature. Can. J. Neurol. Sci. 2016, 43, 486-493. [CrossRef]

140. Hansen, N.; Widman, G.; Witt, J.A.; Wagner, J.; Becker, A.J.; Elger, C.E.; Helmstaedter, C. Seizure control and cognitive improvement via immunotherapy in late onset epilepsy patients with paraneoplastic versus GAD65 autoantibody-associated limbic encephalitis. Epilepsy Behav. 2016, 65, 18-24. [CrossRef]

141. Liu, B.; Zhou, Y.; Meng, L.; Skinner, H. A Survival Case of Super-refractory Status Epilepticus due to Glutamic Acid Decarboxylase Antibodies-associated Limbic Encephalitis. Cureus 2018, 10, e3125. [CrossRef] [PubMed]

142. Boronat, A.; Sabater, L.; Saiz, A.; Dalmau, J.; Graus, F. GABA(B) receptor antibodies in limbic encephalitis and anti-GAD-associated neurologic disorders. Neurology 2011, 76, 795-800. [CrossRef] [PubMed]

143. Jarius, S.; Ringelstein, M.; Haas, J.; Serysheva, I.I.; Komorowski, L.; Fechner, K.; Wandinger, K.P.; Albrecht, P.; Hefter, H.; Moser, A.; et al. Inositol 1,4,5-trisphosphate receptor type 1 autoantibodies in paraneoplastic and non-paraneoplastic peripheral neuropathy. J. Neuroinflamm. 2016, 13, 278. [CrossRef] [PubMed]

144. Berger, B.; Bischler, P.; Dersch, R.; Hottenrott, T.; Rauer, S.; Stich, O. “Non-classical” paraneoplastic neurological syndromes associated with well-characterized antineuronal antibodies as compared to "classical" syndromes-More frequent than expected. J. Neurol. Sci. 2015, 352, 58-61. [CrossRef]

145. Sun, X.; Tan, J.; Sun, H.; Liu, Y.; Guan, W.; Jia, J.; Wang, Z. Anti-SOX1 Antibodies in Paraneoplastic Neurological Syndrome. J. Clin. Neurol. 2020, 16, 530-546. [CrossRef]

146. Yamamoto, T.; Tsuji, S. Anti-Ma2-associated encephalitis and paraneoplastic limbic encephalitis. Brain Nerve 2010, 62, 838-851.

147. Shen, K.; Xu, Y.; Guan, H.; Zhong, W.; Chen, M.; Zhao, J.; Li, L.; Wang, M. Paraneoplastic limbic encephalitis associated with lung cancer. Sci. Rep. 2018, 8, 6792. [CrossRef]

148. Ortega Suero, G.; Sola-Valls, N.; Escudero, D.; Saiz, A.; Graus, F. Anti-Ma and anti-Ma2-associated paraneoplastic neurological syndromes. Neurologia 2018, 33, 18-27. [CrossRef]

149. Kohler, W.; Ehrlich, S.; Dohmen, C.; Haubitz, M.; Hoffmann, F.; Schmidt, S.; Klingel, R.; Kraft, A.; Neumann-Haefelin, T.; Topka, H.; et al. Tryptophan immunoadsorption for the treatment of autoimmune encephalitis. Eur. J. Neurol. 2015, 22, 203-206. [CrossRef]

150. Heine, J.; Ly, L.T.; Lieker, I.; Slowinski, T.; Finke, C.; Pruss, H.; Harms, L. Immunoadsorption or plasma exchange in the treatment of autoimmune encephalitis: A pilot study. J. Neurol. 2016, 263, 2395-2402. [CrossRef]

151. Dogan Onugoren, M.; Golombeck, K.S.; Bien, C.; Abu-Tair, M.; Brand, M.; Bulla-Hellwig, M.; Lohmann, H.; Munstermann, D.; Pavenstadt, H.; Tholking, G.; et al. Immunoadsorption therapy in autoimmune encephalitides. Neurol. Neuroimmunol. Neuroinflamm. 2016, 3, e207. [CrossRef] [PubMed]

152. Rossling, R.; Pruss, H. Apheresis in Autoimmune Encephalitis and Autoimmune Dementia. J. Clin. Med. 2020, 9, 2683. [CrossRef] [PubMed] 
153. Dalakas, M.C. Neurological complications of immune checkpoint inhibitors: What happens when you 'take the brakes off' the immune system. Ther. Adv. Neurol. Disord. 2018, 11, 1756286418799864. [CrossRef]

154. Barbagallo, M.; Vitaliti, G.; Pavone, P.; Romano, C.; Lubrano, R.; Falsaperla, R. Pediatric Autoimmune Encephalitis. J. Pediatr. Neurosci. 2017, 12, 130-134. [CrossRef] [PubMed]

155. Shapiro-Shelef, M.; Calame, K. Regulation of plasma-cell development. Nat. Rev. Immunol. 2005, 5, 230-242. [CrossRef]

156. Kosmidis, M.L.; Dalakas, M.C. Practical considerations on the use of rituximab in autoimmune neurological disorders. Ther. Adv. Neurol. Disord. 2010, 3, 93-105. [CrossRef]

157. Hoftberger, R.; van Sonderen, A.; Leypoldt, F.; Houghton, D.; Geschwind, M.; Gelfand, J.; Paredes, M.; Sabater, L.; Saiz, A.; Titulaer, M.J.; et al. Encephalitis and AMPA receptor antibodies: Novel findings in a case series of 22 patients. Neurology 2015, 84, 2403-2412. [CrossRef]

158. Brummaier, T.; Pohanka, E.; Studnicka-Benke, A.; Pieringer, H. Using cyclophosphamide in inflammatory rheumatic diseases. Eur. J. Intern. Med. 2013, 24, 590-596. [CrossRef]

159. Kanter, I.C.; Huttner, H.B.; Staykov, D.; Biermann, T.; Struffert, T.; Kerling, F.; Hilz, M.J.; Schellinger, P.D.; Schwab, S.; Bardutzky, J. Cyclophosphamide for anti-GAD antibody-positive refractory status epilepticus. Epilepsia 2008, 49, 914-920. [CrossRef]

160. Gea-Banacloche, J.C. Rituximab-associated infections. Semin. Hematol. 2010, 47, 187-198. [CrossRef]

161. Mihara, M.; Kasutani, K.; Okazaki, M.; Nakamura, A.; Kawai, S.; Sugimoto, M.; Matsumoto, Y.; Ohsugi, Y. Tocilizumab inhibits signal transduction mediated by both mIL-6R and sIL-6R, but not by the receptors of other members of IL-6 cytokine family. Int Immunopharmacol. 2005, 5, 1731-1740. [CrossRef]

162. Chavele, K.M.; Merry, E.; Ehrenstein, M.R. Cutting edge: Circulating plasmablasts induce the differentiation of human T follicular helper cells via IL-6 production. J. Immunol. 2015, 194, 2482-2485. [CrossRef]

163. Lee, W.J.; Lee, S.T.; Moon, J.; Sunwoo, J.S.; Byun, J.I.; Lim, J.A.; Kim, T.J.; Shin, Y.W.; Lee, K.J.; Jun, J.S.; et al. Tocilizumab in Autoimmune Encephalitis Refractory to Rituximab: An Institutional Cohort Study. Neurotherapeutics 2016, 13, 824-832. [CrossRef]

164. Benucci, M.; Tramacere, L.; Infantino, M.; Manfredi, M.; Grossi, V.; Damiani, A.; Gobbi, F.L.; Piccininni, M.; Zaccara, G.; Cincotta, M. Efficacy of Tocilizumab in Limbic Encephalitis with Anti-CASPR2 Antibodies. Case Rep. Neurol. Med. 2020, $2020,5697670$. [CrossRef]

165. Randell, R.L.; Adams, A.V.; Van Mater, H. Tocilizumab in Refractory Autoimmune Encephalitis: A Series of Pediatric Cases. Pediatr. Neurol. 2018, 86, 66-68. [CrossRef]

166. Scheibe, F.; Ostendorf, L.; Reincke, S.M.; Pruss, H.; von Brunneck, A.C.; Kohnlein, M.; Alexander, T.; Meisel, C.; Meisel, A. Daratumumab treatment for therapy-refractory anti-CASPR2 encephalitis. J. Neurol. 2020, 267, 317-323. [CrossRef]

167. Nosadini, M.; Mohammad, S.S.; Toldo, I.; Sartori, S.; Dale, R.C. Mycophenolate mofetil, azathioprine and methotrexate usage in paediatric anti-NMDAR encephalitis: A systematic literature review. Eur. J. Paediatr. Neurol. 2019, 23, 7-18. [CrossRef]

168. Dale, R.C.; Gorman, M.P.; Lim, M. Autoimmune encephalitis in children: Clinical phenomenology, therapeutics, and emerging challenges. Curr. Opin. Neurol. 2017, 30, 334-344. [CrossRef]

169. Dutra, L.A.; Abrantes, F.; Toso, F.F.; Pedroso, J.L.; Barsottini, O.G.P.; Hoftberger, R. Autoimmune encephalitis: A review of diagnosis and treatment. Arq. Neuropsiquiatr. 2018, 76, 41-49. [CrossRef]

170. Argyropoulos, G.P.D.; Moore, L.; Loane, C.; Roca-Fernandez, A.; Lage-Martinez, C.; Gurau, O.; Irani, S.R.; Zeman, A.; Butler, C.R. Pathologic tearfulness after limbic encephalitis: A novel disorder and its neural basis. Neurology 2020, 94, e1320-e1335. [CrossRef] 